\title{
VARIATION IN DIETARY HISTORIES AMONG THE IMMIGRANTS OF MACHU PICCHU: CARBON AND NITROGEN ISOTOPE EVIDENCE
}

\author{
VARIACIÓN EN HISTORIAS DIETÉTICAS ENTRE LOS INMIGRANTES DE \\ MACHU PICCHU: EVIDENCIA DE ISÓTOPOS DE CARBONO Y NITRÓGENO
}

\author{
Bethany L. Turner ${ }^{1}$, John D. Kingston ${ }^{2}$, and George J. Armelagos ${ }^{2}$
}

\begin{abstract}
This study estimates dietary composition during infancy and childhood among 71 adults interred at the site of Machu Picchu, a royal Inca estate in the southern highlands of Peru. Recent research suggests that the majority of individuals were members of the cosmopolitian yana and aclla servant classes, and immigrated to the site from different regions; individual dietary histories may have been similarly varied. Diet was estimated at multiple points in early life through characterization of carbon and nitrogen isotope ratios in tooth enamel and dentin, which preserve isotopic values from the first years of life. These data were compared to isotopic data from modern food samples, and analyzed using recently-published statistical models. A subset of individuals also has existing bone collagen isotopic data, which reflects diet from the last decade of life and thus permits comparison over the life course. Results indicate significant variation in enamel $\delta^{13} \mathrm{C}$ (approximately $12 \%$ ), dentin $\delta^{13} \mathrm{C}$ (approximately $9 \%$ ) and $\delta^{15} \mathrm{~N}$ (approximately $8 \%$ o) between individuals across the study population. These findings suggest substantial variability in diet during infancy and childhood, and support interpretations that this population was primarily yanacona or mixed yanaconalacllacona. This study also highlights the utility of multi-tissue isotopic analysis in more nuanced reconstruction of diet in the ancient Andes.
\end{abstract}

Key words: Stable isotopes, teeth, Inca, paleodiet, Precolumbian Andes.

Este estudio estima la composición dietética durante la infancia y la niñez en 71 entierros de adultos del sitio Machu Picchu, una propiedad real Inca en las montañas de Perú. Esta investigación sugiere que la mayoría de los individuos eran miembros de una clase cosmopolita de servidores yana y aclla que inmigraron a este sitio desde diferentes regiones, por lo que sus historias dietéticas tempranas pudieron haber sido variadas. La dieta fue estimada en múltiples puntos de la primera parte de la vida de estos individuos a través de la caracterización de las proporciones de isotópicos estables de carbón y nitrógeno conservados en el esmalte y dentina de la dentadura desde las primeras épocas de vida de los individuos. Estos datos fueron comparados con datos isotópicos de alimentos actuales y analizados con modelos estadísticos recientemente publicados. De un subconjunto de individuos se obtuvieron, además, datos isotópicos del colágeno contenido en los huesos, que reflejan la dieta de la última década de vida de éstos, lo que permite hacer una comparación del ciclo total de vida. Los resultados muestran notables variaciones en las $\delta^{13} \mathrm{C}$ del esmalte (aproximadamente 12\%o) y dentina (aproximadamente 9\%o) y en $\delta^{15} \mathrm{~N}$ de la dentina (aproximadamente 8\%o). Estos resultados sugieren importantes diferencias en la dieta de los individuos durante la infancia y la niñez y apoyan las interpretaciones que esta población era principalmente yanacona o una mezcla yanacona/acllacona. Este estudio destaca también la utilidad de análisis isotópicos sobre distintos tejidos para una reconstrucción más novedosa de la dieta y subsistencia en la prehistoria andina.

Palabras claves: isótopos estables, dientes, Inca, dieta antigua, Andes precolombinos.

Diet is a fundamental aspect of everyday life; it is also a key area of intersection between ecology, political economy and physiological well-being. Accurately mapping dietary characteristics in ancient populations, not only across cultures and time periods but also within single groups or even single life spans, therefore opens an essential window to better understand their constituents.

With extensive ecological and cultural diversity, the Precolumbian Andes is an area for which a better understanding of subsistence and diet provide particular political, economic and cultural insights. The ancient central Andean economy has long been characterized as a "vertical archipelago" in the highland sierra (Murra 1980) in which single ethnic groups cultivated crops and pastured livestock at different altitudinal zones, pooling and redistributing resources in order to maximize production across several ecological systems. The coastal regions of Precolumbian Peru and northern Chile have been

\footnotetext{
1 Department of Anthropology, Georgia State University, Atlanta, GA USA. antblt@langate.gsu.edu

2 Department of Anthropology, Emory University, Atlanta, GA USA. jkingst@emory.edu; antga@ learnlink.emory.edu
} 
seen as areas of "horizontal" economic specialization, with a reliance on marine resources, trade and incipient monetization (Rostworowski 1977). These regional economic differences were sustained under the Inca system of indirect control, meaning that different groups would have had varying access to different food resources depending on where in the state they lived. Moreover, in populations with a substantial degree of immigration and/or emigration, individuals or population subsets may have had widely varying dietary histories Given the synergistic relationship between nutrition and susceptibility to other stressors such as infection (Scrimshaw and San Giovanni 1997), especially early in life (Goldenberg 2003), variation in dietary histories could have also translated to variation in health histories as well.

This study presents carbon and nitrogen isotopic ratios from a large sample of the skeletal population from the Inca royal estate of Machu Picchu in order to estimate dietary composition and the degree of dietary variation. Machu Picchu was a royal estate constructed during the reign of Inca Pachacuti in the mid-fifteenth century (Figure 1), and was inhabited by a permanent population until its eventual abandonment by AD 1570, following the Spanish conquest of Peru in 1532 (Rowe 1990). Archaeological analyses led by Hiram Bingham in the early $20^{\text {th }}$ century recovered 177 individuals from cave interments in three major cemeteries surrounding the site (Bingham 1979 [1930]; Eaton 1916). The three cemetery areas displayed no significant variation in interment contexts, and no significant variation in individual mortuary contexts that might have indicated differential status among the population (Salazar 2001). Moreover, the utilitarian nature of associated grave goods suggests that the Machu Picchu population did not include members of the Inca nobility (Salazar 2001). This suggested non-elite status is supported by ethnohistorical accounts in which Inca royal mummies were attended as revered ancestors in Cuzco and other imperial centers, not interred at royal estates (Rowe 1946). Therefore, the Machu Picchu population likely consisted of individuals from one or more non-elite social classes under the direct control of the Inca state. While several analyses of colonial documents suggest that royal estates such as Machu Picchu would have been managed by permanent yanacona and/or a mixed yanacona/acllacona population, others have suggested that mitmacona labor colonists or even local hatun runa (commoners) may have lived and worked on them as well (Rostworowski de Diez Canseco 1999).

Burger et al. (2003) hypothesize that the population from Machu Picchu consisted of yanacona. Ethnohistorical research describes the yanacona as members of a cosmopolitan servant class who were individually selected by elites and moved about the empire for various services, including permanent residence as retainers at royal estates (Villar Cordova 1966). The yana class typically consisted of males; an analogous class of female retainers was known as the acllacona, or "chosen women" (Rowe 1982; Silverblatt 1978). As such, yana populations and/ or mixed yanalaclla populations would have been assemblages of individuals who had little to no commonality in background; this would theoretically differentiate them from mitmacona or local hatun runa, though mitmaq communities may have themselves been internally heterogeneous (Turner 2008; Turner et al. 2009). The yana or mixed yanalaclla hypothesis is further supported by a recent isotopic study of residential mobility in a larger segment of the Machu Picchu population, in which wide, stochastic and statistically significant variation was found in strontium, oxygen and lead isotopic ratios among its constituents (Turner et al. 2009). These data suggest that the majority of the Machu Picchu population originated from numerous regions of the central Andes and immigrated to the site following childhood, with considerable individual variation in residential origin-a yanal aclla population or an admixture of yana, aclla, and heterogeneous mitmacona. It would therefore be reasonable to assume that wide variation in background could also extend to dietary history, as the central Andes is characterized by a variety of ecozones and by varying modes of subsistence and goods exchange.

Within this overall context, it would therefore be reasonable to assume regional diversity in diet related to subsistence context, which would vary by climate, altitude, aridity and proximity to rivers, lakes and the Pacific Ocean. Based on the wide variation in residential origin suggested for the Machu Picchu population based on mortuary context (Salazar 2001) and $\mathrm{Sr}, \mathrm{Pb}$ and $\mathrm{O}$ isotopic data (Turner et al. 2009), one could reasonably infer that members of the population grew up consuming equally varied diets. This could have important implications for interpreting nutritional status and 


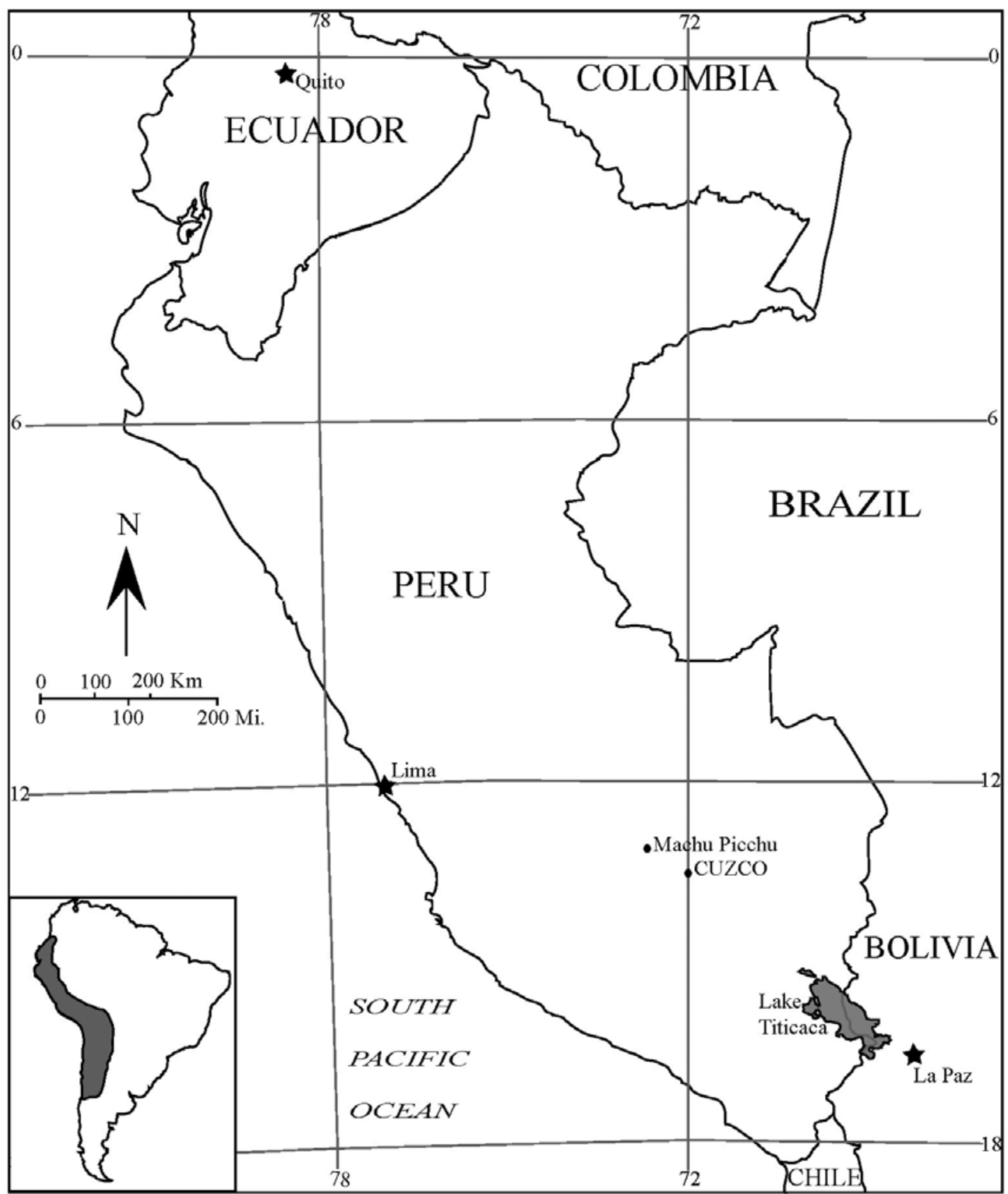

Figure 1. The Central Andes showing the location of Machu Picchu. Andes Centrales, que muestra la ubicación de Machu Picchu.

health among the population (Turner, Kingston, and Armelagos 2009), and for understanding non-elite subsistence practices during the Inca period.

To explore this suggestion, isotopic data directly related to dietary resources are characterized for a large subset of the Machu Picchu population ( $\mathrm{N}=71$ of 177 total) and used to interpret both within-individual and between individual dietary trends. This is made possible through the analysis of multiple isotopic parameters for each individual, characterized from skeletal tissues that develop at different points in life and therefore exhibit isotopic values that reflect dietary patterns from different life stages. Burger et al. (2003) report carbon and nitrogen isotopic data 
for a subset of the Machu Picchu population from bone collagen originally analyzed in 1987; these published data are included here along with new isotopic data characterized from tooth enamel and dentin. Bone remodels during life and represents averaged isotopic values for the last decade or so leading up to death (Manolagas 2000); therefore, bone collagen isotopic data reported by Burger et al. (2003) provide insights into averaged dietary composition towards the end of life. Conversely, enamel crowns form at stable rates during infancy and childhood and show little to-no-turnover once formed; dentin also forms at stable rates during crown formation, though with slightly different timing than corresponding enamel crowns from the same tooth (Hillson 1996). Dentin also shows relatively little turnover compared to bone, unless the tooth sustains trauma or severe wear during life (Hillson 1996, Roberts-Clark and Smith 2000). This study therefore provides a fuller dataset that includes nitrogen and both inorganic and organic carbon isotopic values, from specific in vivo periods. These data are therefore useful in interpreting individual dietary change over the lifespan, and for characterizing diet from periods in constituents' lives prior to their likely immigration to Machu Picchu (Turner et al. 2009).

\section{Stable Isotopes and Dietary Reconstruction}

Isotopic reconstructions of diet in archaeological populations constitute an important and common area of bioarchaeological research, utilizing biochemical measures of the relative importance of constituent food types to individual diets. Isotopic ratios of carbon in bone and enamel carbonate $\left(\delta^{13} \mathrm{C}_{\mathrm{ap}}\right)$ represent carbon drawn from all sources in the diet, including terrestrial or marine animals, and plants with $\mathrm{C}_{3}$ versus $\mathrm{C}_{4}$ photosynthetic pathways (less commonly consumed by humans are plants with crassulean-acid metabolism (CAM) photosynthetic pathways, whose $\delta^{13} \mathrm{C}$ values vary between $\mathrm{C}_{3}$ and $\mathrm{C}_{4}$ ranges). As such, carbonate isotopic values represent a composite dietary signal representing carbohydrates, fats, and protein. In bone and dentin protein, the majority of which is collagen, the same ratios $\left(\delta^{13} \mathrm{C}_{\mathrm{col}}\right)$ appear to disproportionately represent the contribution of carbon found in dietary protein (Ambrose and Norr 1993). Traditionally, carbonate-collagen spacing, or $\Delta^{13} \mathrm{C}_{\mathrm{ap}-\mathrm{col}}$ have been used to estimate the type and proportion of protein in the overall diet (Ambrose 1993, Ambrose and Norr 1993); however, recent research suggests that in vivo metabolic routing of dietary components to different bodily tissues is more complex, and alternate formulae are needed to accurately estimate different dietary components in archaeological populations (Kellner and Schoeninger 2007). Isotopic nitrogen ratios $\left(\delta^{15} \mathrm{~N}\right)$ found in bone and dentin collagen reflect the types of protein (animal, vegetable, leguminous, terrestrial versus marine) incorporated into the diet (DeNiro and Schoeninger 1983), representing trophic-level effects in protein intake associated with organisms' positions in food webs (Ambrose et al. 1997; Ambrose and Norr 1993; Lee-Thorp et al. 1989).

Working from these premises, isotopic studies of Andean populations have provided critical insights into prehistoric Andean subsistence such as those related to movement between regions (Aufderheide et al. 1994, White et al. 2009) and shifts to sedentism (Benfer 1990). Changes in subsistence have also been related to aspects of state formation and consolidation, including increased maize production and consumption (Finucane et al. 2006; Sandness 1992), access to meat (Hastorf 2001), gendered and status-based access to maize products (Hastorf 1996; Ubelaker et al. 1995) and shifting relationships with imperial cores over time (Slovak 2007). Given the direct relationship between Machu Picchu and the Inca state and previously-reported isotopic evidence of a substantial number of immigrants at the site (Turner et al. 2009), assessing dietary histories in this population could provide additional insights into aspects of early-life subsistence, residence and health.

\section{Ancient Andean Diet: An Overview}

Much of what is known about ancient Andean subsistence comes from colonial Spanish accounts, perhaps the most reliable of which come from accounts first published in 1653 by the Jesuit priest Bernabé Cobo (1890-1895 [1653]:194, see also Rowe 1946). Based on these sources, a handful of goods comprised the bulk of utilized food resources leading up to and during the Late Horizon (AD 1438-1532), with broadly distinct but overlapping dietary patterns in highland sierra versus coastal regions. Staple goods included maize (Zea mays); potatoes (Solanum spp.) and other tubers such as maca (Lepidium meyenii) oca (Oxalis tuberosa) and 
ulluco (Ullucus tuberosus); grains such as quinoa (Chenopodium quinoa; also known as chisiya mama or "mother grain" in Quechua), kañiwa (C. pallidicaule) and kiwicha, or amaranth (Amaranthus caudatus); squashes (Curcurbita spp.); peppers such as ají (Capsicum baccatum) and rocoto (C. pubescens); salt; and beans (Phaseoleum spp.) (Cobo 1964 [1653]: Bks. 4, 11, 14). Importantly, kiwicha (A. caudatus) is the only other known $\mathrm{C}_{4}$ plant in the western hemisphere consumed by Precolumbian human populations besides maize. Coastal populations consumed a substantial degree of crayfish and fresh and dried fish such as sardines and anchovies (see Tieszen and Chapman 1993 for taxonomic detail), though there is little evidence to suggest that large, pelagic (deep-sea) fish contributed substantially to the diet (Marcus et al. 1999:6568). These products were also dried and traded for dried llama (Lama glama) meat to the highlands, where they were kept in storehouses (Marcus et al. 1999; Rostworowski 1977). Similarly, communities in proximity to rivers and lakes likely consumed freshwater fish (see Miller et al. 2010 for taxonomic detail). Hunting was strictly regulated by the Inca throughout the empire, while cuy, or guinea pig (Cavia porcellus) and llama were consumed primarily in ceremonial or celebratory contexts (Rowe 1946:217); therefore consumption of meat was likely limited among nonelites in everyday diet. Llama and alpaca (Vicugna pacos) were not utilized for their milk, and dairy appears to have played no part in the diet.

In her review of colonial accounts of Andean diets, Bray (2003:9) notes that the diets of highstatus versus low-status groups in the Inca state primarily differed not in their basic components, but in the quantity and quality of resources, the style of preparation and in the variety of accoutrements. Thus, the nobility consumed more meat and a greater variety of maize-based dishes, while commoner and servant classes consumed proportionately more tubers and greens (Bray 2003:9-10). The distinction of these models is supported by Tomczak's (2003) isotopic study of Late Intermediate Period (AD 1000-1438) populations from the coastal Osmore drainage of southern Peru. In addition, there is a long tradition in the central Andes of community self-sufficiency, meaning that within the vertical or horizontal subsistence models described above, there would likely be less emphasis on long-distance or interregional trade even within an imperial system such as that of the Inca state (Murra 1972).

\section{Methods}

\section{Research design}

As shown in simplified models in Figure 2, the distribution of each isotopic parameter is expected to vary widely and with no discernable modality, as would be the case among yanacona where potentially every member came from a different geographic and/or cultural background. Moreover, variation of dietary isotopic parameters in a yana/ aclla population would be expected to winnow between early- and late-life, as dietary patterns converged following arrival at Machu Picchu. Bi-or multimodality in the distribution of isotopic data would indicate dietary similarities among subsets of the population, as would be expected if the Machu Picchu population was wholly or partly comprised of mitmacona colonists who would likely share similar backgrounds. In a mitmacona population, late-life diet would also be expected to differ from early-life diet, marking subsistence change with relocation to Machu Picchu; however, within-population variation would be consistently lower than that expected for yanacona or a mix of yanacona and acllacona. A population of local hatun runa, including locally-born descendants of earlier immigrants, would be expected to show consistency in diet, varying little in dietary isotopic parameters both early and late in life.

\section{Sample selection}

Individuals from the overall skeletal assemblage were included in the study population based primarily on availability of identifiable permanent teeth, and secondarily by sufficient preservation to estimate sex and age or by notable characteristics such as cranial modification or unusual burial context. The resulting study population $(\mathrm{N}=71)$ is drawn from the three cemetery areas at the site. Tooth enamel was sampled from M1, M2 and M3 from each individual when present, resulting in $\delta^{13} \mathrm{C}_{\mathrm{ap}}$ data representing three distinct time periods for each individual, "Infancy/Early Childhood" (0-3.5 years), "Middle Childhood" (2.5-8 years), and "Adolescence" (9-12 years) following tooth crown developmental periods outlined in Hillson (1996). It is acknowledged that there is substantial individual variability in the exact timing of crown formation (Hillson 1996); therefore these developmental periods are 


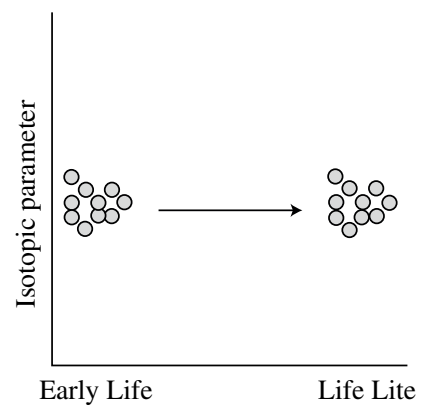

Local Hatun Runa

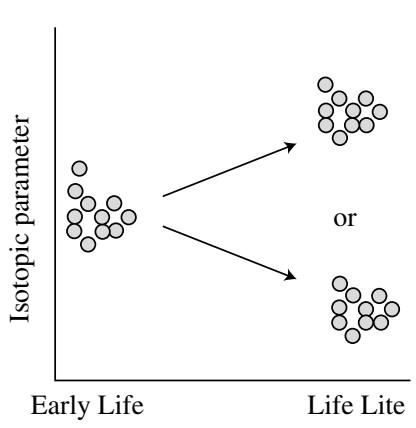

Mitmaq colonists

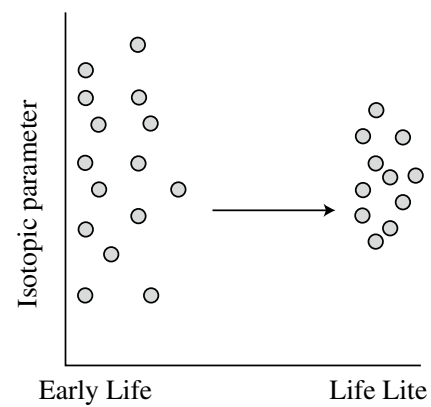

Yana \&/or Aclla

Figure 2. Heuristic models of expected distributions of isotope ratios during tooth enamel and dentin crown formation, according to social class. For each isotope ratio characterized $\left(\delta^{13} \mathrm{C}_{\mathrm{ap}}, \delta^{13} \mathrm{C}_{\mathrm{col}}, \delta^{15} \mathrm{~N}\right)$, a Machu Picchu population consisting primarily of hatun runa (left) would be expected to show little intragroup variation and a lifelong consistency in diet. Conversely, a population consisting primarily of mitmacona (center) would be expected to show little intragroup variation, but show differences between early-life and late-life diet. A population consisting primarily of yanacona (right) would be expected to show wide intragroup variation, with some narrowing of variation by late life, following immigration to Machu Picchu.

Modelos heurísticos de las distribuciones isotópicas previstas durante la formación del esmalte y la dentina, según categoría social. Por cada razón isotópica definida $\left(\delta^{13} C_{a p}, \delta^{13} C_{c o l}, \delta^{15} N\right)$, la población de Machu Picchu, que consiste principalmente en hatun runa (izquierda) se espera poca variación dentro del grupo y una dieta consistente a lo largo de la vida. Recíprocamente, para la población mitmacona (centro) se espera también poca variación dentro del grupo, pero con diferencias significativas entre la edad temprana y final de los individuos. Una población yanacona o yanacona/acllacona (derecha) se espera que presente gran variación dentro del grupo, con alguna reducción de ésta en la etapa final de la vida, luego de su inmigración a Machu Picchu.

general, though they still provide a greater temporal specificity than does the roughly ten-year average represented by bone noted above. Moreover, the use of bulk enamel samples, with developmental periods on the order of years, reduces the effect of seasonal dietary variation and individual variation in specific stages of crown development. Incisors and second premolars were used, respectively as substitutes for first and second molars in the event of their absence.

The ideal sampling design for collagen carbon isotope $\left(\delta^{13} \mathrm{C}_{\mathrm{col}}\right)$ analysis would correspond to that for $\delta^{13} \mathrm{C}_{\mathrm{ap}}$, consisting of a first, second and third permanent molar from each individual, providing a developmental isotopic window spanning birth through roughly fifteen years of age. Moreover, the study population would ideally include all 59 individuals analyzed in Burger et al.'s (2003) earlier isotopic study, providing comparative data from the last decade or so of life for the majority of individuals studied. However, many of the individuals selected by Burger et al. (2003) lacked the necessary teeth for this study, resulting in divergent study populations with only moderate overlap. Second, concerns with minimizing intrusion to in situ teeth, particularly given ongoing controversy surrounding stewardship of the Machu Picchu population
(Harman 2005; Karp-Toledo 2008; Kennedy 2007) led to a modified sampling design centered on collecting minimal dentin to generate viable purified collagen samples. To maximize dentin collagen $\delta^{15} \mathrm{~N}$ and $\delta^{13} \mathrm{C}_{\text {col }}$ results and minimize intrusion, 25-40 $\mathrm{mg}$ of dentin was collected from 22 individuals with adequately exposed and accessible dentin in M1, M2 and/or M3 teeth using a hand-held tool with circular diamond-cutter attachment. Pulp and any areas of secondary dentin formation were abraded off -secondary dentin identified based on its darker color and glossier texture than primary dentin-and teeth with carious lesions were avoided, in order to minimize the potential effects of in vivo dentin turnover (Roberts-Clark and Smith 2000). Finally, the developmental periods represented by dentin crowns overlap with, but also slightly diverge from, their corresponding enamel crowns in overall tooth formation (Hillson 1996). For all of these reasons, different developmental categories are used for isotopic data characterized from dentin rather than enamel, though both are taken from the same individual teeth. M1 dentin represents "Infancy/ Early Childhood" (0-3.5 years), while individuals' M2 and M3 dentin were pooled when both were present, to maximize collagen yield and represent "Middle Childhood/ Adolescence" (2.5-12 years). 
Individuals who only yielded M2 or M3 dentin were still grouped in middle childhood/adolescence, as both are subsumed in that category.

Archaeological llama (L. glama) bone was sampled from four fragmentary ribs collected from the site of Chokepukio, $40 \mathrm{~km}$ southeast of Cusco, Peru with the permission of project director Dr. Gordon McEwan. These data are presented here and are important to interpreting human isotopic data for two reasons. First, llama meat appears to have been consumed at Machu Picchu, based on evidence of charred and cut llama bone (Milner 2003); second, llama herds traveled far and wide throughout the Precolumbian Andes, and may have themselves been quite variable in their $\delta^{13} \mathrm{C}$ values-which would lead to isotopic variability even among humans consuming comparable quantities of llama meat.

\section{Isotopic analysis}

Recent assessments of isolation protocols for archaeological bone collagen (Liden, Takahashi, and Nelson 1995) suggest that methods of extraction using only sodium hydroxide $(\mathrm{NaOH})$ to remove lipids and humic contaminants can decrease collagen yields and fail to completely remove lipids. The dentin samples analyzed here were quite small, the majority weighing less than $30 \mathrm{mg}$; therefore maximizing collagen yield while ensuring collagen purity was of central concern. Thus, a collagen purification protocol designed to minimize contaminants in very small samples was adapted from methods modified from those detailed by Stafford (personal communication 2002), Liden et al. (1995) and Ambrose (1993). Samples were crushed with an agate mortar and pestle and continually flushed for four hours with a 10:5:1 solution of methanol, chloroform and water in a Soxhlet distillation apparatus to remove lipids, then air-dried for 48 hours at room temperature. Samples were then transferred to annealed $15 \mathrm{ml}$ glass tubes with Teflon caps and demineralized in $0.5 \mathrm{M} \mathrm{HCl}$ at $4^{\circ} \mathrm{C}$ until translucent, with periodic replacement of $\mathrm{HCl}$. Samples were then treated with a $0.2 \% \mathrm{KOH}$ solution for $48-72$ hours, depending on sample integrity, to remove humic contaminants, soaked in $0.5 \mathrm{M} \mathrm{HCl}$ for 48 hours at $4^{\circ} \mathrm{C}$, and then solubized in a $0.05 \mathrm{M}$ $\mathrm{HCl}$ solution at $95^{\circ} \mathrm{C}$ for approximately 8 hours. Gelatinized samples were filtered through $.045 \mu \mathrm{m}$ millipore syringe tips into $5 \mathrm{ml}$ borosilicate tubes and freeze dried under vacuum for 36 hours. Llama bone fragments were purified using near identical procedures detailed in Turner et al. (2007).

To characterize a basic terrestrial "menu" based in the southern Peruvian highlands, modern plant samples from indigenous crops of known importance in Precolumbian contexts (Bray 2003) were collected from farms in the village of Huacarpay, outside of Cuzco, Peru and analyzed isotopically along with the four archaeological llama bone samples. Care was taken to ensure that plant samples were from farms that do not utilize chemical fertilizers so as to avoid any potential enriching effect on $\delta^{15} \mathrm{~N}$ due to high-nitrogen inputs (Commisso and Nelson 2007). In a review of colonial literature on traditional Andean culinary practices, Bray (2003:9-10) describes the most common methods for preparing food as boiling, roasting, toasting, grinding and fermenting (i.e., for chicha, a beer-like beverage brewed). Food samples were thus rinsed with $\mathrm{ddH}_{2} \mathrm{O}$ and subjected to boiling, roasting and toasting using laboratory furnaces and hot plates, then freeze-dried and ground prior to characterization of $\delta^{13} \mathrm{C}$ and $\delta^{15} \mathrm{~N}$. Baseline data for terrestrial and aquatic resources from northern Chile are reported by Tieszen and Chapman (1993), while baseline data for freshwater fish from Late Titicaca are reported by Miller et al. (2010), and are referenced here for interpreting the Machu Picchu human isotopic data.

Carbon and nitrogen stable isotope composition of purified collagen and food samples were analyzed on a Carlo Erba CNS analyzer interfaced with a Micromass Prism Series II stable isotope ratio mass spectrometer at the Center for Isotope Geoscience at the University of Florida, Gainesville. The analytical precision of the mass spectrometer was $\pm 0.20 \%$ o for $\delta^{15} \mathrm{~N}$ and $\pm 0.14 \%$ or collagen $\delta^{13} \mathrm{C}$. Samples of tooth enamel carbonate were also purified for inorganic carbon and oxygen isotope analyses; these methods of assessing sample integrity, sample purification, and mass spectrometry are detailed elsewhere (Turner et al. 2009), and for brevity are not repeated her. Statistical analyses were performed using SAS 9.1 (English) and MS Excel for Microsoft Office 2007.

\section{Results}

The isotopic results for the Machu Picchu human dentin and bone samples are summarized in Table 1. Results for analyzed food samples are 
Table 1. Summary of human dietary isotopic results by individual $(\mathrm{N}=71)$. Resumen de los resultados isotópicos por individuo $(N=71)$.

\begin{tabular}{|c|c|c|c|c|c|c|c|c|c|c|c|c|}
\hline Catalog Number & $\begin{array}{l}\text { Age at Death } \\
\text { (years) }^{1}\end{array}$ & $\operatorname{Sex}{ }^{1}$ & $\begin{array}{c}\text { IEC } \\
\delta^{13} C_{a p}\end{array}$ & $\begin{array}{c}\mathrm{MC} \\
\delta^{13} \mathrm{C}_{\mathrm{ap}}\end{array}$ & $\begin{array}{c}\mathrm{AD} \\
\delta^{13} \mathrm{C}_{\mathrm{ap}}\end{array}$ & $\begin{array}{l}\text { Dentin } \\
\text { Collagen } \\
\text { \% Yield }\end{array}$ & $\begin{array}{c}\text { IEC } \\
\delta^{13} \mathrm{C}_{\mathrm{col}}\end{array}$ & $\begin{array}{l}\text { IEC } \\
\delta^{15} \mathrm{~N}\end{array}$ & $\begin{array}{c}\mathrm{MC} / \mathrm{AD} \\
\delta^{13} \mathrm{C}_{\mathrm{col}}\end{array}$ & $\begin{array}{c}\mathrm{MC} / \mathrm{AD} \\
\delta^{15} \mathrm{~N}\end{array}$ & $\begin{array}{c}\text { Bone } \\
\delta^{13} \mathrm{C}_{\mathrm{col}}{ }^{2}\end{array}$ & $\begin{array}{l}\text { Bone } \\
\delta^{15} \mathrm{~N}^{2}\end{array}$ \\
\hline PA3195 G41 & $40-50$ & $\mathrm{~F}$ & -4.3 & -4.5 & & & & & & & & \\
\hline PA0531 G70 & & & -12.7 & & -12.3 & & & & & & & \\
\hline PA4747 G3B & & & -5.2 & -5.5 & & & & & & & & \\
\hline PA3192 G40 & $30-40$ & $\mathrm{~F}$ & -12.0 & -11.8 & -11.3 & & & & & & & \\
\hline PA3163 G9 & $20-25$ & M & -12.8 & & -9.0 & 18.3 & & & -16.6 & 11.3 & & \\
\hline PA4761 G99 & Adult & M & -9.4 & -8.9 & -8.2 & & & & & & & \\
\hline PA3232 G77 & $40-50$ & $\mathrm{~F}$ & -5.5 & -4.4 & -5.7 & 10.2 & -11.9 & 11.7 & & & -12.2 & 8.7 \\
\hline PA3168 G16 & $25-30$ & M & -7.4 & -8.2 & -7.7 & & & & & & & \\
\hline PA3246 G102 & & & -4.2 & -4.7 & -4.5 & 25.2 & & & -13.0 & 8.6 & -13.3 & 7.2 \\
\hline PA3211 G52A & $30-40$ & M & & -6.5 & -5.4 & 18.9 & & & -13.9 & 8.5 & -17.7 & 8.9 \\
\hline PA3186 G37 & $20-30$ & $\mathrm{~F}$ & -2.8 & -5.8 & -5.4 & & & & & & & \\
\hline PA3179 G31 & $30-40$ & $\mathrm{~F}$ & -4.3 & -4.9 & -4.4 & & & & & & & \\
\hline PA3191 G40 & $30-45$ & $\mathrm{~F}$ & -9.9 & -10.7 & -5.7 & & & & & & & \\
\hline PA3248 G107 & Young Adult & M & -8.9 & -8.8 & & 21.8 & -14.8 & 12.9 & & & -10.3 & 9.7 \\
\hline PA3202 G47A & 5 to 6 & & -6.9 & -5.6 & & 19.3 & & & -13.4 & 7.4 & & \\
\hline PA0524 G46 & $17-20$ & $\mathrm{~F}$ & -6.6 & -5.5 & & & & & & & & \\
\hline PA0522 G8 & Adult & $\mathrm{F}$ & -5.2 & & & 19.7 & -12.0 & 12.2 & & & & \\
\hline PA3194 G41 & $30-35$ & M & -4.2 & -3.4 & & & & & & & & \\
\hline PA3158 G4G & & & & -3.7 & & & & & & & & \\
\hline PACoMd G37 & Adult & F & & & -2.4 & 18.9 & & & -10.9 & 11.1 & & \\
\hline PA0525 G55 & & & -6.3 & -3.4 & & & & & & & & \\
\hline PA3206 G49 & $18-22$ & $\mathrm{~F}$ & & & & 18.8 & -14.3 & 10.7 & & & -12.7 & 9.8 \\
\hline PA3187 G37 & $30-40$ & $\mathrm{~F}$ & -4.1 & -2.9 & & & & & & & & \\
\hline PA3160 G5 & $25-35$ & M & & -2.4 & & & & & & & & \\
\hline PA3221 G63 & $25-35$ & $\mathrm{~F}$ & -3.9 & -4.9 & & & -13.2 & 10.2 & & & -10.5 & 9.1 \\
\hline PA3209 G50 & $50+$ & $\mathrm{F}$ & -3.8 & & -3.4 & & & & & & & \\
\hline PA3222 G65 & 8 to 9 & & -4.7 & -7.5 & & 13.7 & -12.0 & 12.0 & & & & \\
\hline PA3158 G4F & & & -4.9 & & & & & & & & & \\
\hline PA3159 G4B & Young Adult & M & -6.1 & & & & & & & & & \\
\hline PA3158 G4C & Adult & M & -6.4 & -3.6 & & & & & & & & \\
\hline PA3158 G4C & $50+$ & $\mathrm{F}$ & & -8.3 & & & & & & & & \\
\hline PA3158 G4A & Young Adult & M & -12.6 & -12.4 & & & & & & & & \\
\hline PA3158 G4B & & & & -5.5 & & & & & & & & \\
\hline PA3165 G11 & $50-60$ & $\mathrm{~F}$ & & -4.8 & & & & & & & & \\
\hline PA3196 G42 & $40-50$ & M & -10.9 & -10.5 & & & & & & & & \\
\hline PA3157 G3A & $30-40$ & $\mathrm{~F}$ & -7.9 & -7.1 & -5.9 & & & & & & & \\
\hline PA3208 G50 & 11 to 13 & & -3.8 & -3.9 & & & & & & & & \\
\hline PA3164 G9B & $20-25$ & M & & -6.7 & & & & & & & & \\
\hline PA3243 G93 & $30-45$ & $\mathrm{~F}$ & -1.1 & -1.1 & -1.5 & & & & & & & \\
\hline PA3228 G72 & 10 to 11 & & -3.3 & -3.8 & & & & & & & & \\
\hline PA3238 G84 & $17-20$ & M & -5.2 & -4.2 & -2.9 & 12.6 & -12.7 & 10.0 & & & -10.1 & 9.6 \\
\hline PA3227 G71 & $19-24$ & M & & -5.5 & -11.7 & 21.2 & & & -12.0 & 24.4 & -16.3 & 12.8 \\
\hline PA3173 G23 & $16-18$ & M & -6.5 & -6.8 & & 10.4 & & & -15.9 & 10.0 & -15.6 & 9.2 \\
\hline PA3220 G62A & $20-30$ & M & -3.7 & -4.5 & -5.5 & & & & & & & \\
\hline PA3197 G42 & $55-65$ & $\mathrm{~F}$ & -4.8 & & & & & & & & & \\
\hline PA3156 G1 & $19-23$ & $\mathrm{~F}$ & -6.7 & -6.1 & & & & & & & & \\
\hline PA4746 G2A & Adult & M & -2.8 & -2.4 & & & & & & & & \\
\hline
\end{tabular}


Continuation Table 1.

\begin{tabular}{|c|c|c|c|c|c|c|c|c|c|c|c|c|}
\hline Catalog Number & $\begin{array}{l}\text { Age at Death } \\
{\text { (years) })^{1}}^{\text {and }}\end{array}$ & $\operatorname{Sex}^{1}$ & $\begin{array}{c}\text { IEC } \\
\delta^{13} \mathrm{C}_{\mathrm{ap}}\end{array}$ & $\begin{array}{c}\mathrm{MC} \\
\delta^{13} \mathrm{C}_{\mathrm{ap}}\end{array}$ & $\begin{array}{c}\mathrm{AD} \\
\delta^{13} \mathrm{C}_{\mathrm{ap}}\end{array}$ & $\begin{array}{l}\text { Dentin } \\
\text { Collagen } \\
\% \text { Yield }\end{array}$ & $\begin{array}{c}\text { IEC } \\
\delta^{13} \mathrm{C}_{\mathrm{col}}\end{array}$ & $\begin{array}{l}\text { IEC } \\
\delta^{15} \mathrm{~N}\end{array}$ & $\begin{array}{c}\mathrm{MC} / \mathrm{AD} \\
\delta^{13} \mathrm{C}_{\mathrm{col}}\end{array}$ & $\begin{array}{c}\mathrm{MC} / \mathrm{AD} \\
\delta^{15} \mathrm{~N}\end{array}$ & $\begin{array}{c}\text { Bone } \\
\delta^{13} \mathrm{C}_{\mathrm{col}}{ }^{2}\end{array}$ & $\begin{array}{l}\text { Bone } \\
\delta^{15} \mathrm{~N}^{2}\end{array}$ \\
\hline PA4746 G2B & Adult & & -3.3 & -2.1 & & & & & & & & \\
\hline PA3161 G5B & Middle Adult & $\mathrm{F}$ & & -11.8 & & 15.6 & & & -18.8 & 13.7 & & \\
\hline PA0521 G7 & $15-17$ & & -2.2 & -1.4 & & 23.2 & -9.1 & 8.3 & & & -12.4 & 9.1 \\
\hline PA3166 G13 & $45-55$ & $\mathrm{~F}$ & -12.8 & -13.4 & & & & & & & & \\
\hline PA3182 G32 & $30-35$ & M & -5.7 & -4.2 & & & & & & & & \\
\hline PA3184 G34 & $40-50$ & $\mathrm{~F}$ & -6.2 & -5.3 & & & & & & & & \\
\hline PA3189 G38 & $35-45$ & $\mathrm{~F}$ & -6.7 & -4.4 & & & & & & & & \\
\hline PA3190 G39 & $20-29$ & $\mathrm{~F}$ & -6.9 & -8.6 & -7.2 & & & & & & & \\
\hline PA3199 G42 & $50+$ & M & & -11.5 & & & & & & & & \\
\hline PA3205 G48B & $15-18$ & M & -7.2 & -8.2 & & & & & & & & \\
\hline PA3207 G50B & Young Adult & & & -4.5 & -4.7 & & & & & & & \\
\hline PA3214 G53 & $50+$ & M & -8.6 & -7.8 & & 23.3 & -14.5 & 10.5 & & & -9.9 & 9.4 \\
\hline PA3219 G61 & $30-40$ & $\mathrm{~F}$ & -5.5 & -3.7 & -4.6 & & & & & & & \\
\hline PA3220 G62B & $18-21$ & $\mathrm{~F}$ & -7.3 & -9.2 & -5.7 & & & & & & & \\
\hline PA3222 G65F & Adult & $\mathrm{F}$ & -7.2 & & & & & & & & & \\
\hline PA3230 G75 & $25-35$ & M & -7.6 & -5.0 & -5.1 & 11 & & & -13.1 & 10.5 & -13.2 & 7.3 \\
\hline PA3231 G75 & $30-40$ & M & -12.6 & -13.5 & -11.9 & 21.3 & -18.3 & 13.9 & & & & \\
\hline PA3233 G77 & $25-35$ & M & -13.3 & -11.9 & -12.1 & & & & & & & \\
\hline PA3235 G80 & $45-55$ & $\mathrm{~F}$ & -6.9 & -7.1 & & & & & & & & \\
\hline PA3236 G81 & $20-30$ & M & -12.9 & -13.1 & -10.8 & 21 & -18.7 & 16.5 & & & & \\
\hline PA3237 G82 & $25-35$ & $\mathrm{~F}$ & -4.0 & -4.0 & -2.8 & & & & & & & \\
\hline PA3239 G84 & $35-45$ & M & & -3.4 & & & & & & & & \\
\hline PA3245 G98 & & & & -4.1 & & 14.2 & & & -11.5 & 12.0 & -10.2 & 8.3 \\
\hline PA3247 G107 & $18-21$ & M & -4.1 & & & 21.8 & -11.7 & 13.2 & & & & \\
\hline
\end{tabular}

Sex: $\mathrm{M}=$ Male, $\mathrm{F}=$ Female. Acronyms used throughout: $\mathrm{IEC}=$ Infancy/Early Childhood; $\mathrm{MC}=$ Middle Childhood; $\mathrm{AD}=$ Adolescence; $\mathrm{MC} / \mathrm{AD}=$ Includes pooled dentin samples from teeth representing MC and AD periods. ${ }^{1}$ Data from Verano (2003) ${ }^{2}$ Data from Burger et al. (2003).

summarized in Table 2. Carbon isotopic results for the modern plant samples are corrected for postindustrial enrichment of atmospheric ${ }^{12} \mathrm{C}$, in order to make these data comparable with archaeological llama and human $\delta^{13} \mathrm{C}$. No systematic or significant difference was found in $\delta^{13} \mathrm{C}$ or $\delta^{15} \mathrm{~N}$ of food samples based on laboratory cooking/preparation technique. Notably, bone collagen $\delta^{13} \mathrm{C}$ and, to a lesser degree, $\delta^{15} \mathrm{~N}$, vary in the four llama specimens analyzed, suggesting some variability in camelid diet.

Before summarizing isotopic results, it is important to address the absence of carbon/nitrogen $(\mathrm{C} / \mathrm{N})$ ratios in the dentin collagen isotopic results. $\mathrm{C} / \mathrm{N}$ ratios are a common measure of sample integrity, and collagen samples from preserved bone or dentin are considered unaltered if their $\mathrm{C} / \mathrm{N}$ ratios fall within a range found in living bone, i.e. 2.6 to 3.4 (Schoeninger et al. 1989). The absence of $\mathrm{C} / \mathrm{N}$ ratios among the dentin samples in this study is due entirely to the minute amounts of collagenous material purified from each individual; there was simply not enough harvestable collagen to produce isotopic data and the \% $\mathrm{C}$ and $\% \mathrm{~N}$ necessary to calculate $\mathrm{C} / \mathrm{N}$ ratios using the mass spectrometer described above. However, the majority of these samples can be considered unaltered by diagenetic processes for several reasons. The majority of the human remains from Machu Picchu were recovered from above-ground cave interments, meaning that many of the individuals had no contact between their dentition and burial soils; while exposure to scavengers or other taphonomic processes was noted during excavation (Eaton 1916; Verano 2003), this context minimizes the likelihood of elemental exchange between hard tissue substrates and surrounding soils and groundwater. Moreover, while Burger et al. (2003) do not report $\mathrm{C} / \mathrm{N}$ ratios, a subset of bone collagen from the Machu Picchu 
Table 2. Summary of dietary isotopic baseline data generated in the present study. Resumen de la base de datos isotópicos de alimentos actuales generados en este estudio.

\begin{tabular}{|c|c|c|c|c|}
\hline Specimen & Common Name & Food Type & $\delta^{13} \mathrm{C}(\% o)$ & $\delta^{15} \mathrm{~N}(\% o)$ \\
\hline Zea mays & Maize & Grain, boiled & -11.8 & 7.8 \\
\hline Solanum sp. & Potato & Tuber, raw & -26.6 & \\
\hline Solanum sp. & Chuño & Tuber, boiled & -26.9 & 4.9 \\
\hline Solanum sp. & Moraya & Tuber, boiled & -26.7 & 7.0 \\
\hline \multirow[t]{4}{*}{ Lama glama } & \multirow[t]{4}{*}{ Llama } & Camelid bone collagen & -17.5 & 6.2 \\
\hline & & Camelid bone collagen & -10.6 & 6.8 \\
\hline & & Camelid bone collagen & -20.0 & 4.1 \\
\hline & & Camelid bone collagen & -14.8 & 6.0 \\
\hline \multirow[t]{5}{*}{ Chenopodium quinoa } & \multirow[t]{5}{*}{ Quinoa } & Grain, raw & -25.2 & 7.7 \\
\hline & & Grain, raw & -26.0 & 8.7 \\
\hline & & Grain, raw & -25.1 & 8.0 \\
\hline & & Grain, toasted & -25.9 & 8.8 \\
\hline & & Grain, boiled & -25.2 & 9.0 \\
\hline \multirow[t]{3}{*}{ Amaranthus caudatus } & \multirow[t]{3}{*}{ Kiwicha } & Grain, raw & -12.8 & 13.6 \\
\hline & & Grain, toasted & -12.6 & 14.0 \\
\hline & & Grain, boiled & -12.3 & 13.5 \\
\hline \multirow[t]{11}{*}{ Phaseoleum lunatus } & \multirow[t]{11}{*}{ Lima Bean } & Legume, raw & -25.0 & 0.9 \\
\hline & & Legume, raw & -25.0 & 0.2 \\
\hline & & Legume, raw & -26.0 & 0.1 \\
\hline & & Legume, raw & -24.1 & 0.9 \\
\hline & & Legume, raw & -24.3 & 1.4 \\
\hline & & Legume, raw & -24.2 & 0.9 \\
\hline & & Legume, raw & -24.7 & 0.8 \\
\hline & & Legume, raw & -24.8 & 0.8 \\
\hline & & Legume, raw & -24.8 & 0.3 \\
\hline & & Legume, raw & -24.8 & 0.5 \\
\hline & & Legume, boiled & -26.7 & 0.5 \\
\hline
\end{tabular}

population $(n=10)$ was purified here using the same techniques as for dentin and analyzed for $\mathrm{C} / \mathrm{N}$ ratios, all of which fall between 2.7-2.9, within the acceptable range. Additionally, percent collagen yields were used as indicators of integrity; the Type I collagen that represents the vast bulk of skeletal protein is considered to comprise $20-30 \%$ of the overall skeletal mass, including dentin (Becker et al. 1986, Butler 1992). Using the minimum of $5 \%$ and maximum of $25 \%$ that is the standard in most isotopic dietary studies (Schoeninger et al. 1989, White and Schwarcz 1994), any individuals whose collagen yields fell below $5 \%$ or above $25 \%$ were excluded from analysis. Moreover, plots of percent yields with $\delta^{15} \mathrm{~N}$ and $\delta^{13} \mathrm{C}_{\mathrm{col}}$ (not included here) indicate no significant linear or modal relationship between percent yields and either $\delta^{13} \mathrm{C}\left(\mathrm{R}^{2}=0.07\right)$ or $\delta^{15} \mathrm{~N}\left(\mathrm{R}^{2}=0.02\right)$. Moreover, Pearson $(\rho \%$ yield, IEC $\delta 13 \mathrm{Ccol}=-0.243, \mathrm{P}=0.47)$ and Spearman $\left(\rho_{\%}\right.$ yield, $\mathrm{MCAD} \delta 13 \mathrm{Ccol}=0.322, \mathrm{P}=0.364 ; \rho_{\%}$ yield, IEC $\delta 15 \mathrm{~N}$ $=0.050, \mathrm{P}=0.884 ; \rho \%$ yield, $\operatorname{MCAD} \delta 15 \mathrm{~N}=-0.164, \mathrm{P}=$ 0.651 ) tests of correlation between percent yields and collagenous isotopic values are non-significant.

As summarized in Figure $3, \delta^{13} \mathrm{C}_{\mathrm{ap}}$ at all three developmental periods ranges over $10 \%$; mean values for Infancy/Early Childhood, Middle Childhood, and Adolescence are, respectively, $-6.8 \%,-6.3 \%$ o and $-6.6 \%$, with standard deviations of $3.2 \%$, $3.2 \%$ and $3.3 \%$. In addition, the magnitude of change in $\delta^{13} \mathrm{C}_{\mathrm{ap}}$ within each individual across early-life developmental periods also widely varies. Of those individuals for whom multiple teeth were 


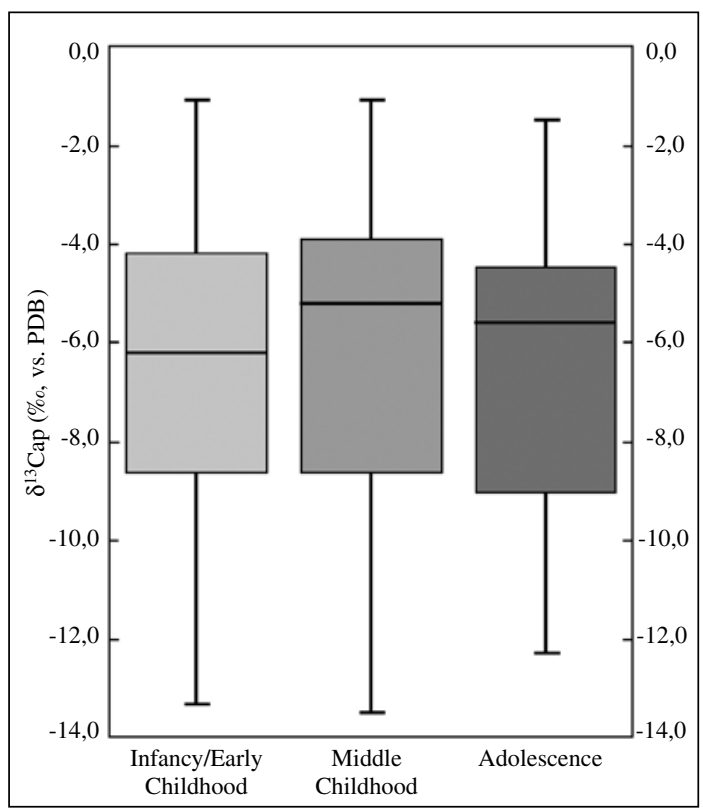

Figure 3. Box-and-Whiskers plots of enamel $\delta^{13} \mathrm{C}_{\text {ap }}$ by developmental period. Each plot represents a five-number summary for each developmental period: the top whisker represents the maximum value in the isotopic range, while the bottom whisker represents the minimum value; the top and bottom ends of each box represent the upper and lower quartiles, respectively, and the line within each box represents the median value.

El diagrama de caja para medidas de esmalte $\delta^{13} C_{a p}$ por periodo etario. Cada traza representa un resumen de cinco medidas por cada periodo etario. La parte superior del diagrama representa el valor máximo en la gama isotópica, mientras que la parte de abajo el valor mínimo. Los bordes superior e inferior de cada caja representan los cuartiles máximo y mínimo, respectivamente, y la línea central la mediana.

characterized, $\delta^{13} \mathrm{C}_{\mathrm{ap}}$ was enriched from Infancy/ Early Childhood to Middle Childhood by up to $1 \%$ o in fifteen individuals and by between 1-3\%o in six individuals; $\delta^{13} \mathrm{C}_{\mathrm{ap}}$ depleted during this same period by up to $1 \%$ in fourteen individuals and by between $1-3 \%$ in six individuals. Even greater variation was observed in the magnitude of change between Middle Childhood and Adolescence: $\delta^{13} C_{a p}$ enriched by up to $1 \%$ in six individuals and depleted by up to $1 \%$ in another six individuals; however, $\delta^{13} C_{a p}$ enriched by $1-3 \%$ in eight individuals and depleted by $1-3 \%$ in one individual, and $\delta^{13} \mathrm{C}_{\mathrm{ap}}$ enriched by over $3 \%$ in two individuals and depleted by over $3 \%$ in one individual. These varying degrees of change within individuals' enamel isotopic values suggest diversity in the extent of dietary change within individuals' lives as well.
Individual $\delta^{13} \mathrm{C}_{\mathrm{col}}$ in Infancy/Early Childhood and Middle Childhood/Adolescence ranges upwards of 5\%, as shown in Figure 4; mean values for Infancy/Early Childhood and Middle Childhood/ Adolescence are, respectively, $-13.6 \%$ and $-13.9 \%$, with standard deviations of $2.5 \%$ and $2.2 \%$. These ranges also indicate marked difference in diet among those individuals analyzed, particularly in dietary protein. An additional parameter of estimating the nature of dietary protein is collagenous $\delta^{15} \mathrm{~N}$, which serves primarily as a proxy of dietary protein composition. Nitrogen isotopes also enrich in a stepwise manner of approximately $3 \%$ o through trophic webs (Schoeninger and DeNiro 1984), and can be affected by environmental and physiological factors, noted below. As shown in Figure 4, $\delta^{15} \mathrm{~N}$ values vary widely throughout Infancy/Early Childhood and Middle Childhood/Adolescence; mean $\delta^{15} \mathrm{~N}$ values for these two periods are each $11.8 \%$, with respective standard deviations of $2.2 \%$ o and $4.8 \%$. Ranges of both Infancy/Early Childhood and Middle Childhood/Adolescence $\delta^{15} \mathrm{~N}$ exceed $8 \%$, from $8.3 \%$ o to $16.5 \%$ and $7.4 \%$ o to $24.4 \%$, respectively.

One individual exhibits a highly enriched $\delta^{15} \mathrm{~N}$ value in M2 of $24.4 \%$, which accounts for the large standard deviation in Middle Childhood/ Adolescence. This outlier individual, an adult male with pronounced annular cranial modification, displays a percent yield within the normal range, and is not an outlier in his $\delta^{13} \mathrm{C}_{\text {col }}$ value $(-12.0 \%$ ). It is possible that this extreme degree of enrichment in $\delta^{15} \mathrm{~N}$ is due to prolonged breastfeeding -especially from a mother whose own diet was rich in marine

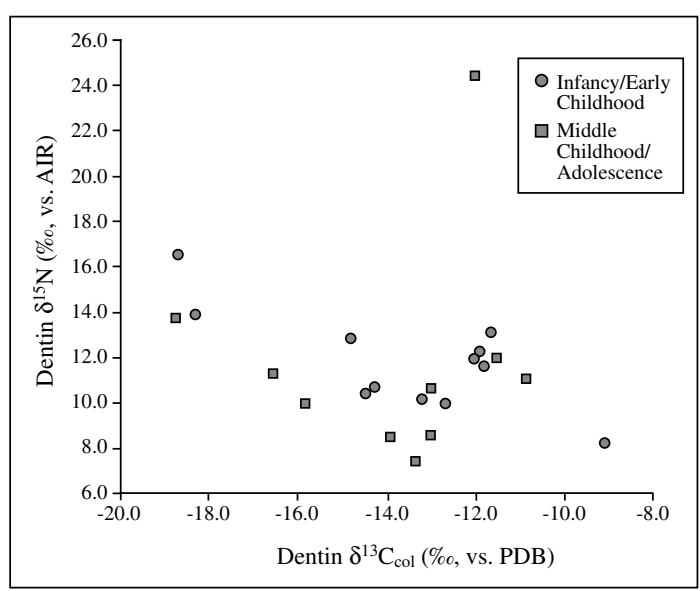

Figure 4. Plot of dentin collagen $\delta^{15} \mathrm{~N}$ vs. $\delta^{13} \mathrm{C}$. Trazas de colágeno en la dentina $\delta^{15} N$ versus $\delta^{13} C_{c o l}$. 
fish - to consumption of marine fish himself, to metabolic abnormalities, residential origin in an arid ecozone (Ambrose 1991), or some combination of these factors. Srontium, lead and oxygen isotopic data from this individual tentatively suggest that he immigrated to Machu Picchu from the coastal region of southern Peru or northern Chile (Turner et al. 2009), which could support interpretations of substantial marine fish in his diet; however, this interpretation is tentative and does not preclude physiological or pathological processes as contributing factors. If this $\delta^{15} \mathrm{~N}$ outlier is excluded from the Middle Childhood/Adolescent cohort, the $\delta^{15} \mathrm{~N}$ range for the study population reduces from $17.0 \%$ o to $6.3 \%$, which is still a substantial degree of variation.

Isotopic values for the four archaeological llama bones sampled display considerable variation; as summarized in Table 2 and Figure $5, \delta^{13} \mathrm{C}_{\mathrm{col}}$ ranges from $-10.6 \%$ o to $-20.0 \%$, while $\delta^{15} \mathrm{~N}$ ranges from $4.1 \%$ o to $6.8 \%$. These values may indicate variation in dietary patterns among different individual llama, particularly since llama caravans were used for long-distance transport of goods throughout the Precolumbian Andes. Therefore, some admixture in a given herd might be expected through variation in feeding and husbanding strategies (Finucane et al.
2006; Izeta et al. 2009) and trade of animals from different herds, or through calving during a longdistance caravan, where offspring would vary in their diets from parent generations. This interpretation is supported by recent research (Yacobaccio, Morales, and Samec 2009) that suggests a stepwise, inverse relationship between llama $\delta^{13} \mathrm{C}_{\mathrm{col}}$ and grazing altitude in modern specimens from the Argentine puna ecozone. This variation likely extends to archaeological specimens throughout the Andes, given migratory range of llama caravans throughout the Precolumbian Andes (Lynch 1983), regional variation in local biota (Gomez Molina and Little 1981) and different climatological and ecological contexts in different regions affecting the metabolism of plants within the same taxa (Tieszen 1991).

\section{Discussion}

The Machu Picchu population range in $\delta^{13} \mathrm{C}_{\mathrm{ap}}$ encompasses much of the values found in $\mathrm{C}_{4}$ and $\mathrm{C}_{3}$ food plants and their herbivore consumers (Ambrose 1993, DeNiro and Schoeninger 1983). Similarly, the $\delta^{13} \mathrm{C}_{\mathrm{col}}$ isotopic range among the Machu Picchu population spans the values available for terrestrial and aquatic protein sources in the region (Table 2, Figure 5; see also Miller et al.

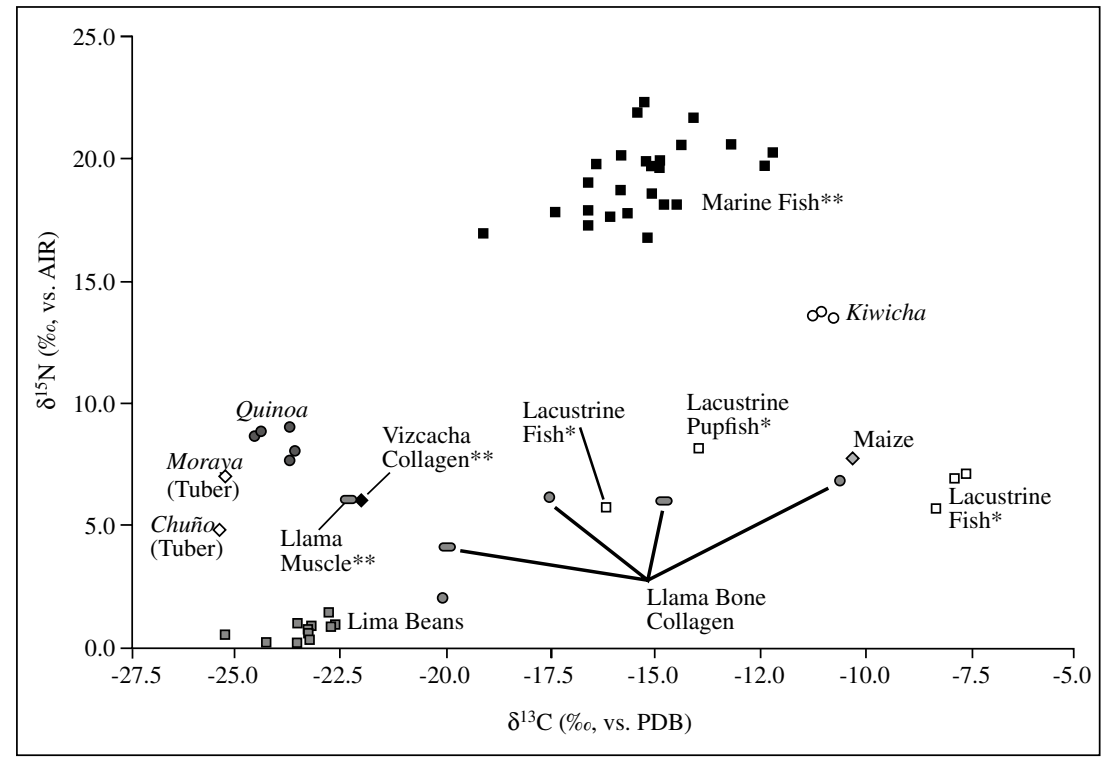

Figure 5. Plot of $\delta^{15} \mathrm{~N}$ vs. $\delta^{13} \mathrm{C}$ for indigenous food resources likely available to Central Andean highland populations. *Isotopic data from archaeological Lake Titicaca fish from Miller et al. (2010). **Mean isotopic data from Tieszen and Chapman (1993). Trazas de $\delta^{13} C_{c o l}$ versus $\delta^{13} C_{a p}$ de los alimentos locales posiblemente disponibles para las poblaciones de las sierras de los Andes Centrales. *Valores isotópicos de pescados arqueológicos del Lago Titicaca obtenido de Miller et al. (2010). **Valores isotópicos promedio obtenidos de Tieszen y Chapman (1993). 
2010, and Tieszen and Chapman 1993). This human isotopic range also exceeds that found in the four archaeological llama specimens analyzed here, meaning that it is unlikely that a single population with common backgrounds were simply eating meat from isotopically variable llama. The human isotopic variation speaks to a greater variation in overall diet, rather than one that is biased by variation among the diets of consumed llama. Interpreting this variation in terms of reconstructing what people were eating during these periods is complex, and requires consideration of a number of influences, potential confounders, and subsistence scenarios.

As discussed earlier, $\delta^{13} \mathrm{C}_{\text {ap }}$ data serve as proxies of whole diet, including carbohydrates, proteins and fats, while $\delta^{13} \mathrm{C}_{\mathrm{col}}$ data serve disproportionately, but not exclusively, as proxies of the dietary protein (Ambrose and Norr 1993; Jim et al. 2004). Kellner and Schoeninger (2007:1120-1121) present a new analytical model to estimate $\delta^{13} \mathrm{C}_{\text {overall }}$ diet from $\delta^{13} \mathrm{C}_{\text {ap }}$ and $\delta^{13} \mathrm{C}_{\text {diet protein }}$ from $\delta^{13} \mathrm{C}_{\text {col }}$ as an alternative to traditional carbonate apatite -collagen offsets $\left(\delta^{13} \mathrm{C}_{\mathrm{ap}}-\delta^{13} \mathrm{C}_{\mathrm{col}}\right.$, i.e. $\left.\Delta^{13} \mathrm{C}_{\mathrm{ap} \text {-col }}\right)$, which they argue do not provide useful estimates of the proportion and source of dietary protein. The application of their regression model here, to estimate dietary composition in the 21 individuals with enamel and dentin $\delta^{13} \mathrm{C}$ isotopic data, yields insights into early-life dietary variability among this subset of the Machu Picchu study population, shown in Figure 6.

Individuals were plotted along three regression lines controlling for dietary protein source from this analytical model. As shown in Figure 6, individuals varied substantially in their source of dietary energy and dietary protein. Many of the individuals appear to have consumed a majority of dietary energy from $\mathrm{C}_{4}$ sources such as maize or kiwicha; three individuals consumed mostly $\mathrm{C}_{3}$ energy sources such as legumes, quinoa, tubers and other vegetables, and five individuals consumed mixed $\mathrm{C}_{3} / \mathrm{C}_{4}$ energy sources. Only three individuals fall along the $\mathrm{C}_{3}$ protein line with a position suggesting a majority of dietary energy from $\mathrm{C}_{3}$ sources as well, while two others fall near the $\mathrm{C}_{3}$ protein line but position closer to mixed $C_{3} / C_{4}$ dietary energy. Only one individual falls between the marine protein and $\mathrm{C}_{4}$ protein lines, while the outlier individual discussed above falls almost directly on the marine protein line and well into the range of $100 \% \mathrm{C}_{4}$ energy. The majority of individuals consumed most of their dietary energy from $\mathrm{C}_{4}$ sources, and plot between the protein lines for $\mathrm{C}_{3}$ on the one hand, and marine and $\mathrm{C}_{4}$ protein on the other. This suggests that a substantial number of individuals in this subset of 21 consumed $\mathrm{C}_{4}$ energy and $\mathrm{C}_{4}$ protein sources

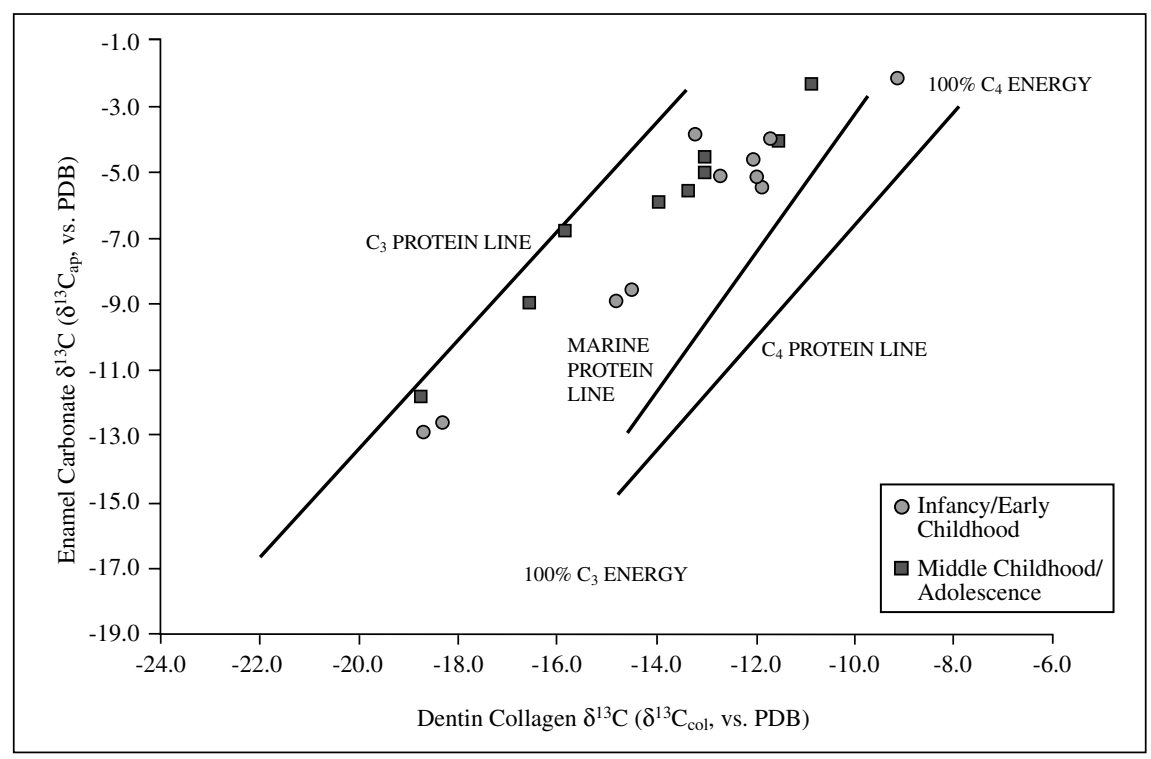

Figure 6. Plot of $\delta^{13} \mathrm{C}_{\mathrm{ap}}$ vs. $\delta^{13} \mathrm{C}_{\mathrm{col}}$ with regression lines for dietary estimation from Kellner and Schoeninger (2007:1122). Trazas de $\delta^{13} C_{\text {col }}$ versus $\delta^{13} C_{a p}$ con líneas de regresiones para estimaciones dietarias tomadas de Kellner y Schoeninger (2007:1122). 
with some inclusion of $\mathrm{C}_{3}$ protein. However, the spread of the data indicates variability in dietary protein and energy composition within this general characterization.

Among this majority, fully assessing the diversity in both energy and protein sources is likely impacted at least in part by three key factors. The first is the variation in llama bone collagen from four samples analyzed here (Table 2), particularly the $9.4 \%$ range in $\delta^{13} \mathrm{C}$. Llama caravans routinely traveled considerable distances to facilitate movement of goods throughout different regions during the Inca period; it is likely that llamas varied in their dietary composition depending on the relative abundance of $\mathrm{C}_{3}$ and $\mathrm{C}_{4}$ foliage in different ecozones. Individuals could therefore consume similar proportions of llama meat but still differ in their tissue $\delta^{13} \mathrm{C}_{\mathrm{col}}$.

The second factor influencing estimation of energy and protein sources is the overlap between freshwater fish from sites near Lake Titicaca (Miller et al. 2010) and maize, shown in Figure 5. While these two sources of protein overlap isotopically, they diverge substantially in their nutrient composition. However, several of the individuals displaying early-life carbon isotopic values in the $\mathrm{C}_{4}$ protein range also exhibit depleted strontium isotopic values and heavier $\delta^{18} \mathrm{O}$ values, both of which tentatively suggest residential origin in coastal regions (see discussion in Turner et al. 2009) rather than the Lake Titicaca region. However, the ${ }^{87} \mathrm{Sr} /{ }^{86} \mathrm{Sr}$ and $\delta^{18} \mathrm{O}$ data for individuals in the $\mathrm{C}_{4}$ dietary range are widely distributed, precluding firm interpretation of coastal, marine-based diets or highland diets heavy in maize or other terrestrial $\mathrm{C}_{4}$ sources.

Finally, estimating protein and energy sources is influenced by the inclusion of native, high-protein grains of high nutritional quality in the Andean dietary repertoire. Kiwicha (amaranth) is a $\mathrm{C}_{4}$ grain with a protein content of 13-18\%, higher than many other grains (National Research Council 1989:143) and substantially higher than Andean legumes such as lima beans (5.3\%). Quinoa, a $\mathrm{C}_{3}$ grain, has an even higher protein content of $16-23 \%$. This is lower than the protein content found in animal sources such as llama charqui (dried meat), which has as much as $80 \%$ protein (Garcia et al. 2001). Nonetheless, both quinoa and kiwicha could have contributed significant dietary protein in addition to their carbohydrate energy. In addition, the $\delta^{13} \mathrm{C}$ of kiwicha is similar to that of maize, and substantially higher than that of quinoa. Moreover, the mean $\delta^{15} \mathrm{~N}$ of kiwicha analyzed here is 13.5 , substantially enriched relative to maize and quinoa (Table 2 ) and most other terrestrial plants (Schoeninger, Iwaniec, and Glander 1997), and intermediate between that of marine fish and $\mathrm{C}_{4}$ terrestrial grazers (Tieszen and Chapman 1993). Kiwicha therefore represents an additional dietary resource enriched in both $\delta^{13} \mathrm{C}$ and $\delta^{15} \mathrm{~N}$ that could limit the extent to which terrestrial animal, plant and marine foods can be distinguished in estimating human diet in Andean contexts. The presence in the Andes of these highprotein, high-energy crops that overlap somewhat in $\delta^{13} \mathrm{C}$ and $\delta^{15} \mathrm{~N}$ with other common resources represents additional sources of dietary variability to consider.

A new regression model for estimating diet from both $\delta^{13} \mathrm{C}$ and $\delta^{15} \mathrm{~N}$ from Froehle et al. (2009) is not yet available in published literature, limiting the inclusion of $\delta^{15} \mathrm{~N}$ in estimating diet as has been done with $\delta^{13} \mathrm{C}$ (Kellner and Schoeninger 2007). However, assuming a roughly 3\%o enrichment between food source and consumer, the $\delta^{15} \mathrm{~N}$ of the various protein sources consumed by most of the individuals in the study group during Infancy/ Early Childhood and Middle Childhood (with the exception of the aforementioned outlier) ranged between $4.4 \%$ and $13.5 \%$. These values span the range of most, but not all, of available protein sources. However, two possible confounders must be taken into account in estimating dietary protein from tooth $\delta^{15} \mathrm{~N}$. The first is that $\delta^{15} \mathrm{~N}$ has been found to enrich in animals living in arid environments due to physiological mechanisms of water conservation (Ambrose 1991); this applies to areas of the central Andes, especially the hyper-arid coastal deserts, as an isotopic study of residential mobility at Machu Picchu identified numerous individuals who may have originated in coastal regions (Turner et al. 2009). Since areas of the central Andes, especially the coastal desert, are characterized by moderate to extreme aridity, this could be of potential concern. However, there is no correlation between dentin $\delta^{15} \mathrm{~N}$ and previously-reported enamel $\delta^{18} \mathrm{O}$ (Turner et al. 2009) from corresponding teeth-among an admittedly small sample size. Since $\delta^{18} \mathrm{O}$ in teeth reflects the $\delta^{18} \mathrm{O}$ of consumed water, which in turn is affected by climatic influences on evaporative pressure such as aridity, temperature and altitude, this lack of correlation suggests that enrichment through physiological means of water conservation is less 
likely a major influence on $\delta^{15} \mathrm{~N}$ values. However, recent work by Knudson (2009) demonstrates substantial $\delta^{18} \mathrm{O}$ variation within populations determined to be "local" via Sr isotope analysis. This suggests that more work is needed to fully understand the various environmental and metabolic factors influencing $\delta^{18} \mathrm{O}$ in humans, including correlation with $\delta^{15} \mathrm{~N}$ in arid contexts.

The second confounder is the likely role that breastfeeding played in $\delta^{15} \mathrm{~N}$ enrichment in M1 dentin, which forms during Infancy/Early Childhood, when individuals were likely consuming breastmilk as part of their diet. Infant tissues are typically enriched in $\delta^{15} \mathrm{~N}$ by 2-3\% relative to older children and adults as they represent additional trophic-level fractionation between maternal diet and breastmilk (Fogel et al. 1989). However, the resolution of the sampling here is insufficient to estimate the age at which individuals received supplementary foods or ceased breastfeeding, since almost all individuals are represented by a single dentin sample.

It is perhaps most conservative to assume some additional enrichment in $\delta^{15} \mathrm{~N}$ among the Infancy/ Early Childhood sample cohort relative to maternal tissues, indicating at least some breastfeeding during the development of M1 dentin. Accounting for additional fractionation between maternal diet and maternal breastmilk, an assumed enrichment of $4.5 \%$ between plant and animal protein and IEC dentin suggests a dietary protein base for the Machu Picchu population during Infancy/Early Childhood of 3.7-12.0\%o. These revised estimates suggest that individuals (or rather, they and their mothers) consumed dietary protein from a wide variety of sources. Overall combined $\delta^{13} \mathrm{C}$ and $\delta^{15} \mathrm{~N}$ results suggest that none of the individuals in the population obtained their dietary protein exclusively from leguminous sources such as lima beans (Figure 5). Several individuals are enriched in $\delta^{15} \mathrm{~N}$ while relatively depleted in $\delta^{13} \mathrm{C}_{\mathrm{col}}$, suggesting at least partial reliance on freshwater fish or $\mathrm{C}_{3}$ browser meat for dietary protein, and similar to findings (Falabella et al. 2007) among populations in central Chile.

\section{Change in diet across the individual lifespan}

Within Early-Life. As noted above, a substantial degree of variation was found in the magnitude of change in $\delta^{13} \mathrm{C}_{\mathrm{ap}}$ among those individuals for whom multiple tooth enamel samples were analyzed.
While the majority of individuals exhibited less than $1 \%$ o change in their $\delta^{13} C_{a p}$ between Infancy/ Early Childhood and Middle Childhood, or between Middle Childhood and Adolescence, over two dozen individuals exhibited either enrichment or depletion between 1-3\%o, and three individuals exhibited enrichment or depletion in excess of $3 \%$. Enamel $\delta^{13} \mathrm{C}_{\mathrm{ap}}$ represents an average of the carbon metabolized from the full range of dietary sources, including carbohydrates, protein and lipids; it is therefore difficult to reconstruct what particulars of the diet changed during early life. However, one general interpretation that can be made is that while some individuals were consuming a relatively homogenous diet -isotopically speaking-during infancy and childhood, others experienced moderate change in their diets, and others may have experienced more substantial shifts. Previously-reported $\delta^{18} \mathrm{O}$ data, which is a commonly-used indicator of local ecological context and therefore residential origin (Turner et al. 2009), is similarly varied for these individuals in both between-individual and within-individual variation. While some individuals show very little change in $\delta^{18} \mathrm{O}$, others display a degree of change that suggests proximity to markedly different sources of drinking water, i.e. in different ecological contexts. Therefore, the variation in dietary change within individuals' early lives may be related to regional differences between ecozones during infancy, childhood, or adolescence. These data represent a window into the lives of ancient populations that is uncommon in isotopic research, and speaks to the potential for reconstructing multiple episodes of change across individual lifespans in better interpreting diet, nutrition, and health.

Early- vs. Late-Life. A pre-existing isotopic dataset for part of the Machu Picchu population from Burger et al. (2003) permits comparison among 13 individuals in this study population who have both dentin and bone collagen results (Table 1). Unfortunately, bone $\delta^{13} C_{\text {ap }}$ was not characterized in this earlier study, which precludes early- vs. late-life comparison with the enamel values discussed above; however, insights can be gained in examining early- vs. late-life dietary trends using $\delta^{13} \mathrm{C}_{\mathrm{col}}$ and $\delta^{15} \mathrm{~N}$. For this subset, mean bone collagen $\delta^{13} \mathrm{C}_{\text {col }}$ is $-12.6 \%$ with a standard deviation of $2.6 \%$ and range of $7.8 \%$; mean $\delta^{15} \mathrm{~N}$ is $9.2 \%$ with a standard deviation of $1.4 \%$ and a range of 
5.6\%o. In comparing these data with corresponding dentin data, mean $\delta^{13} \mathrm{C}_{\mathrm{col}}$ shows an increase of $1 \%$ o between dentin and bone results, but similar standards of deviation throughout. Mean $\delta^{15} \mathrm{~N}$ declines by roughly $2 \%$ and shows a much smaller standard deviation in bone versus dentin results, especially between bone and dentin representing Middle Childhood/Adolescence. This tentatively suggests wider variation in sources of dietary protein earlier in life versus the years leading up to death; taken in conjunction with isotopic estimates of residential origin (Turner et al. 2009) and the results shown in Figure 6, this points to a greater diversity in dietary protein sources prior to migration to Machu Picchu.

It should also be noted that bone collagen isotopic data represent averaged values over the last decade or so of life (Manolagas 2000). Since almost half $(\mathrm{N}=10)$ of the dentin samples in the study population represent a developmental period extending to as late as fifteen years, it is possible that some lingering isotopic values from early-life were incorporated into bone collagen averages, especially for individuals who died in their twenties or even early thirties. While this would not extend to the entire study sample, it is worth noting that the dentin and bone collagen datasets could have areas of overlap, and that variation in the former may contribute to some of the variation in the latter.

Individuals in this small subset of the study population vary in the magnitude of change between early- and late-life in both $\delta^{13} \mathrm{C}_{\mathrm{col}}$ and $\delta^{15} \mathrm{~N}$. However, most individuals exhibit some enrichment in $\delta^{13} \mathrm{C}_{\mathrm{col}}$ and depletion in $\delta^{15} \mathrm{~N}$. This suggests a decrease in the proportion of ${ }^{15} \mathrm{~N}$-enriched dietary protein and an increase in the proportion of $\mathrm{C}_{4}$ food resources. The depletion in $\delta^{15} \mathrm{~N}$ would be expected at least in part from individuals whose dentin was sampled from first molars and therefore represents values from infancy/early childhood due to supplementation and weaning, though a shift in protein sources independent of this process could also play a role, especially among those whose dentin was sampled from later-developing molars. One could interpret the slight enrichment in $\delta^{13} \mathrm{C}_{\mathrm{col}}$ as suggesting that there was little change in sources of carbon from dietary protein, but this does not necessarily mean little change in dietary protein sources, given the overlap in $\delta^{13} \mathrm{C}$ values between kiwicha, $\mathrm{C}_{4}$ grazers, and maize on the one hand, and between freshwater fish, $\mathrm{C}_{3}$ browsers and $\mathrm{C}_{3}$ plants on the other. Unfortunately, the dietary estimates from dentin and enamel samples (Figure 6) are less useful in comparisons between early- and late-life $\delta^{13} \mathrm{C}$ data since no bone carbonate apatite was characterized in Burger et al.'s (2003) study. However, teasing apart possible shifts in dietary protein sources given this overlap in $\delta^{13} \mathrm{C}_{\mathrm{col}}$ is facilitated by examining carbon isotopic values in conjunction with $\delta^{15} \mathrm{~N}$. Slight enrichment of $\delta^{13} \mathrm{C}$ in conjunction with depletion in $\delta^{15} \mathrm{~N}$, tentatively points to increased maize consumption as a potential explanation for both trends. Several individuals appear to have slightly depleted or shown little to no change in their $\delta^{13} \mathrm{C}$, but it is suggested here that the direction of change may actually be towards enrichment that is masked by differences in sample purification methods between the bone collagen and dentin collagen datasets.

The collagen purification methods used by Lee-Thorpe and van der Merwe in their 1987 characterization of the Machu Picchu bone collagen for Burger et al. (2003) reflected prevailing methodologies at that time. However, subsequent studies by Liden et al. (1995) suggest that aspects of those common purification techniques, specifically the use of $\mathrm{NaOH}$, may be insufficient in removing humic contaminants and lipids from tissue samples. Hence, the methods used here for dentin collagen purification take this into account, and incorporate more meticulous procedures for lipid removal through Soxhlet distillation with methanol/chloroform solutions and $\mathrm{KOH}$ for removal of humic contaminants. This is a critical point since lipids are depleted in $\delta^{13} \mathrm{C}$ relative to proteins, including collagen (DeNiro and Epstein 1977; Tieszen et al. 1983). Therefore, even if one assumes a very slight depletion in all of the resulting bone collagen data due to residual lipids (for example, $0.5 \%$ ), this would shift the magnitudes of change in $\delta^{13} \mathrm{C}$ seen in these individuals such that all but a few individuals show zero change, slight enrichment, or moderate enrichment between dentin and bone collagen values. This hypothetical shift accounting for methodological differences would have no effect on $\delta^{15} \mathrm{~N}$. This supports the interpretation that more than a few individuals show some enrichment in $\delta^{13} \mathrm{C}$, possibly due to increased maize consumption between early and late life. This also corresponds with interpretations of maize consumption at Machu Picchu by Burger et al. (2003). 


\section{Conclusion}

In sum, the population from Machu Picchu appears to have consumed a wide variety of foods early in life, spanning the range of subsistence contexts attributed to Inca-period Andean populations. The population appears to have varied widely in the sources of dietary energy and protein contributing to individuals' early-life diets. This variation in diet extends, though to a lesser degree, into adulthood, though the degree to which adult variation could be inflated by residual isotopic values from earlier in life is unclear. However, results tentatively suggest that maize became a more important dietary component, and that ${ }^{15} \mathrm{~N}$-enriched protein sources such as meat, fish or kiwicha became less important, following relocation to Machu Picchu, a notion echoed by Burger et al. (2003). However, the magnitude of this potential dietary shift is itself widely variable; dietary composition for some individuals appears to have remained (isotopically speaking) largely unchanged while others appear to have experienced marked change.

The variability in these dietary estimates corresponds to that in previously-reported $\mathrm{Sr}, \mathrm{Pb}$ and O isotopic data (Turner et al. 2009) and further supports the hypothesis that the Machu Picchu study population was drawn from a variety of regions, with a variety of subsistence regimes and dietary patterns, and represents a diverse assemblage of individuals. Multivariate analysis to directly analyze these previously-reported $\mathrm{Sr}, \mathrm{Pb}$ and $\mathrm{O}$ isotopic data with the $\mathrm{C}$ and $\mathrm{N}$ isotopic data reported here is unfeasible due to several factors, including the small sample size, marked difference in the scale of the data from each isotopic parameter, and the marked difference in dietary and/or environmental substrates that each isotopic parameter represents. However, as shown in Figure 7, these early- versus late-life carbon and nitrogen isotopic data best fit the heuristic model (Figure 2) proposed for a population of yanacona or mix of yanacona and acllacona; any mitmacona present would have had more variation in backgrounds than is suggested in ethnohistorical analyses (Rowe 1982). The residential isotopic data reported in Turner et al. (2009) also correspond to a similar heuristic model proposed therein for a population of yanacona and acllacona: namely one of wide, stochastic variation in isotopic data lacking any clear modality in their distribution. The possible increase in maize consumption of the population later in life also suggests an elevated status among the population, given the ceremonial and cultural importance of maize and maize products such as chicha. Yanacona and acllacona are described in ethnohistorical work (Pease 1982; Rowe 1982; Villar Cordova 1966) as sharing elevated status among non-elite classes in the Inca state. Despite noted limitations in sample size, this study therefore illustrates the potential of using multiple organic and inorganic tissues per individual in examining both between- and within-individual isotopic variation, mapping variation and life-course change in diet linked to status-mediated movement in the Precolumbian Andes.

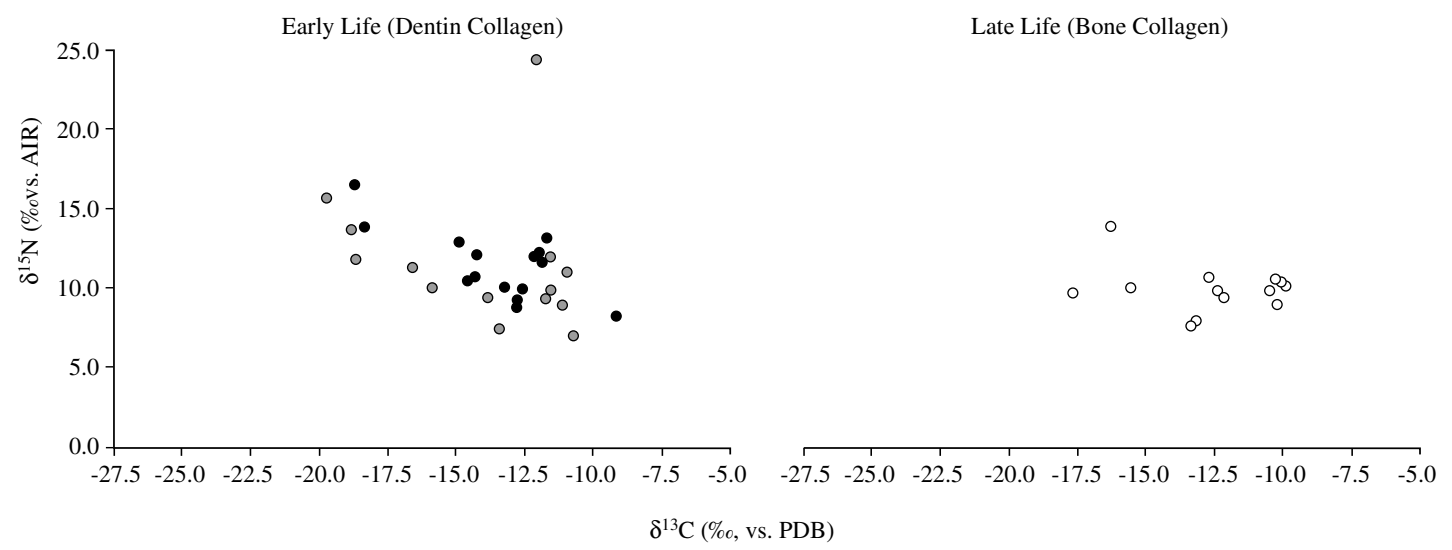

Figure 7. Plot of early-life and late-life $\delta^{15} \mathrm{~N}$ vs. $\delta^{13} \mathrm{C}_{\mathrm{col}}$ data for the Machu Picchu human population, for assessment against the heuristic models in Figure 2.

Trazas de $\delta^{13} C_{c o l}$ versus $\delta^{13} C_{a p}$ presentes en las etapas temprana y tardía de la población humana de Machu Picchu, valorizada con los modelos heurísticos de las distribuciones isotópicas previstas en la Figura 2. 
Acknowledgments: This study was supported by the National Science Foundation (BCS-0615409) and the Graduate School of Arts and Sciences at Emory University. Modern food samples were brought to the United States in accordance with a permit from the APHIS department of the USDA. The authors thank the curators and staff of the Peabody Museum of Natural History at Yale University, for permission to study and sample the
Machu Picchu human and faunal collection. Many thanks also to Jason Curtis in the Department of Geological Sciences at the University of Florida Gainesville for mass spectrometry analysis, and to Gordon McEwan and Foilan Iturriaga Guzman for assistance in procuring modern food samples. Four anonymous reviewers provided insightful and thorough comments that were very helpful in improving this manuscript.

\section{References Cited}

Ambrose, S.H.

1991 Effects of diet, climate and physiology on nitrogen isotope abundances in terrestrial foodwebs. Journal of Archaeological Science 18:293-317.

1993 Isotopic analysis of paleodiets: Methodological and interpretive considerations. In Investigations of Ancient Human Tissue: Chemical Analyses in Anthropology, edited by M.K. Sandford, pp. 59-130. Gordon and Breach Science Publishers, Langhorne.

Ambrose, S.H., B.M. Butler, D.B. Hanson, R.L. Hunter-Anderson, and H.W. Krueger

1997 Stable isotopic analysis of human diet in the Marianas archipelago, Western Pacific. American Journal of Physical Anthropology 104:343-361.

Ambrose, S.H., and L. Norr

1993 Experimental evidence for the relationship of the carbon isotope ratios of whole diet and dietary protein to those of bone collagen and carbonate. In Prehistoric Human Bone: Archaeology at the Molecular Level, edited by J.B. Lambert and G. Grupe, pp. 1-37. Springer-Verlag, Berlin.

Aufderheide, A.C., M.A. Kelley, M. Rivera, L. Gray, L.L. Tieszen, E. Iversen, H.R. Krouse, and A. Carevic

1994 Contributions of chemical dietary reconstruction to the assessment of adaptation by ancient Highland immigrants (Alto-Ramirez) to coastal conditions at Pisagua, North Chile. Journal of Archaeological Science 21:515-524.

Becker, J., D. Schuppan, H. Benzian, T. Bals, E.G. Hahn, C. Cantaluppi, and P. Reichart

1986 Immunohistochemical distribution of collagen types IV, V, and VI and of pro-collagens types I and III in human alveolar bone and dentine. Journal of Histochemistry and Cytochemistry 34:1417-1429.

Benfer, R.A.J.

1990 The preceramic period site of Paloma, Peru: Bioindications of improving adaptation to sedentism. Latin American Antiquity 1:284-318.

Bingham, $\mathrm{H}$.

1979 [1930] Machu Picchu: Citadel of the Incas. Hacker Art Books, New York.

Bray, T.L.

2003 Inka potterey as culinary equipment: Food, feasting and gender in imperial state design. Latin American Antiquity 14:3-28.

Burger, R.L., J.A. Lee-Thorp, and N.J. van der Merwe 2003 Rite and crop in the Inca State revisited: An isotopic perspective from Machu Picchu and beyond. In The 1912 Yale
Peruvian Scientific Expedition Collections from Machu Picchu, vol. 85, edited by R.L. Burger and L.C. Salazar, pp. 119-137. Yale University Publications in Anthropology, New Haven. Butler, W.T.

1992 Dentin extracellular matrix and dentinogenesis. Operative Dentistry 5:18-23.

Cobo, B.

1890-1895 [1653] Historia del Nuevo Mundo (Publicado por Primera Vez con Notas y Otras Ilustraciones de D. Marcos Jiménez de la Espada). Sociedad de Bibliófilos Andaluces, Sevilla.

1964 [1653] Historia del Nuevo Mundo. Biblioteca de Autores Españoles. Ediciones Atlas, Madrid.

Commisso, R.G., and D.E. Nelson

2007 Patterns of plant $\delta 15 \mathrm{~N}$ values on a Greenland Norse farm. Journal of Archaeological Science 34:440-450.

DeNiro, M.J., and S. Epstein

1977 Mechanism of carbon isotope fractionation associated with lipid synthesis. Science 197:261-263.

DeNiro, M.J., and M.J. Schoeninger

1983 Stable carbon and nitrogen isotope ratios of bonecollagen-variations within individuals, between sexes, and within populations raised on monotonous diets. Journal of Archaeological Science 10:199-203.

Eaton, G.F.

1916 The Collection of osteological material from Machu Picchu. Memoirs of the Connecticut Academy of Arts and Sciences.

Falabella, F., M.T. Planella, E. Aspillaga, L. Sanhueza, and R.H. Tykot

2007 Dieta en sociedades alfareras de Chile Central: aporte de análisis de isótopos estables. Chungara Revista de Antropología Chilena 39:5-27.

Finucane, B., P.M. Agurto, and W.H. Isbell

2006 Human and animal diet at Conchopata, Peru: Stable isotope evidence for maize agriculture and animal management practices during the Middle Horizon. Journal of Archaeological Science 33:1766-1776.

Fogel, M.L., N. Tuross, and D. W. Owsley

1989 Nitrogen isotope tracers of human lactation in modern and archaeological populations. Annual Report of the Director of the Geophysical Laboratory, 1988-1989 Carnegie Institution, Washington, DC. pp. 111-117.

Froehle, A.W., C.M. Kellner, and M.J. Schoeninger 2009 A Three-variable analysis of carbon and nitrogen isotope values discriminates between dietary energy and 
protein sources in prehistoric humans. American Journal of Physical Anthropology 132:193-194.

Garcia, F.A., I.Y. Mizubuti, M.Y. Kanashiro, and M. Shimokomaki

2001 Intermediate moisture meat product: Biological evaluation of charqui meat protein quality. Food Chemistry 75:405409.

Goldenberg, R.L.

2003 The plausibility of micronutrient deficiency in relationship to perinatal infection. Journal of Nutrition 133.

Gomez Molina, E., and A. Little

1981 Geoecology of the Andes: The natural science basis for research planning. Mountain Research and Development $1: 115-144$.

Harman, D.

200590 years later, Peru battles yale over Incan artifacts. Christian Science Monitor December 29. http://www. csmonitor.com/2005/1229/p01s03-woam.html

Hastorf, C.A.

1996 Gender, space and food in prehistory. In Contemporary Archaeology in Theory, vol. 460-484, edited by R.W. Preucel and I. Hodder. Blackwell Press, Oxford.

2001 Agricultural production and consumption. In Empire and Domestic Economy, edited by T.N. D'Altroy and C.A. Hastorf, pp. 155-178. Kluwer Academic/Plenum Publishers, New York.

Hillson, S.

1996 Dental Anthropology. University Press, Cambridge.

Izeta, A.D., A.G. Laguens, M.B. Marconetto, and M.C. Scattolin

2009 Camelid handling in the Meridional Andes during the First Millenium AD: A preliminary approach. International Journal of Osteoarchaeology 19:204-214.

Jim, S., S.H. Ambrose, and R.P. Evershed

2004 Stable carbon isotopic evidence for differences in the dietary origin of bone cholesterol, collagen and apatite: Implications for their use in palaeodietary reconstruction. Geochimica Et Cosmochimica Acta 68:61-72.

Karp-Toledo, E.

2008 The lost treasure of Machu Picchu. The New York Times February 23.

Kellner, C.M., and M.J. Schoeninger

2007 A simple carbon isotope model for reconstructing prehistoric human diet. American Journal of Physical Anthropology 133:1112-1127.

Kennedy, R.

2007 Yale officials agree to return Peruvian artifacts. The New York Times September 17.

Knudson, K.J.

2009 Oxygen isotope analysis in a land of environmental extremes: The complexities of isotopic work in the Andes. International Journal of Osteoarchaeology 19:171-191.

Lee-Thorp, J.A., J.C. Sealy, and N.J. van der Merwe 1989 Stable carbon isotope ratio differences between bonecollagen and bone apatite, and their relationship to diet. Journal of Archaeological Science 16:585-599.

Liden, K., C. Takahashi, and D.E. Nelson

1995 The effects of lipids in stable carbon-isotope analysis and the effects of $\mathrm{NaOH}$ treatment on the composition of extracted bone-collagen. Journal of Archaeological Science 22:321-326.
Lynch, T.F.

1983 Camelid pastoralism and the emergence of Tiwanaku civilization in the South-Central Andes. World Archaeology 15:1-14.

Manolagas, S.

2000 Birth and death of bone cells: Basic regulatory mechanisms and implications for the pathogenesis and treatment of osteoporosis. Endocrine Reviews 21:115-137.

Marcus, J., J. D. Somber, and C. Glew. 1999. Fish and Mammals in the Economy of an Ancient Peruvian Kingdom. Proceedings of the National Academy of Sciences 96:6564-6570.

Miller, M.J., J.M. Capriles, and C.A. Hastorf

2010 The fish of Lake Titicaca: Implications for archaeology and changing ecology through stable isotope analysis. Journal of Archaeological Science 37:317-327.

Murra, J.V.

1972 El Control Vertical de un Máximo de Pisos Ecológicos en la Economía de las Sociedades Andinas. In Visita de la Provincia de León de Huánuco (1562), vol. 2, edited by J.V. Murra, pp. 429-476. Universidad Nacional Hermilio Valdizán, Huánuco.

1980 The Economic Organization of The Inka State. JAI Press, Greenwich.

National Research Council

1989 Lost Crops of the Incas: Little-Known Plants of the Andes with Promise for Worldwide Cultivation. National Academy Press, Washington, DC.

Roberts-Clark, D., and A.J. Smith

2000 Angiogenic growth factors in human dentine matrix. Archives of Oral Biology 45:1013-1016.

Rostworowski de Diez Canseco, M.

1977 Etnia y Sociedad: Costa Peruana Prehispánica. Instituto de Estudios Peruanos, Lima.

1999 History of the Inca Realm. Translated by Harry B. Iceland. Cambridge University Press, Cambridge.

Rowe, J.H

1946 Inca culture at the time of the Spanish conquest. In Handbook of South American Indians, Vol. 2: The Andean Civilizations, edited by J.H. Steward, pp. 183-330. Bureau of American Ethnology Bulletin 143, vol. 2.

1982 Inca policies and institutions relating to the cultural unification of the empire. In The Inca and Aztec States, 1400-1800: Anthropology and History, edited by G.A. Collier, R.I. Rosaldo, and J.D. Wirth, pp. 93-118. Academic Press, New York.

1990 Machu Picchu a la luz de documentos de siglo XVI. Histórica 14:139-154.

Salazar, L.C.

2001 Inca religion and mortuary ritual at Machu Picchu. In Mortuary Practices and Ritual Associations: Shamanic Elements in Prehistoric Funerary Contexts in South America, British Archaeological Reports International Series, edited by E.J. Currie and J.E. Staller, pp. 117-127. Archaeopress, Oxford.

Sandness, K.L.

1992 Temporal and Spatial Dietary Variability in the Prehistoric Lower and Middle Osmore Drainage: The Carbon and Nitrogen Isotope Evidence. MA Thesis, University of Nebraska at Lincoln.

Schoeninger, M.J., and M.J. DeNiro

1984 Nitrogen and carbon isotopic composition of bonecollagen from marine and terrestrial animals. Geochimica Et Cosmochimica Acta 48:625-639. 
Schoeninger, M.J., U.T. Iwaniec, and K.E. Glander 1997 Stable isotope ratios monitor diet and habitat use in New World monkeys. American Journal of Physical Anthropology 103:69-83.

Schoeninger, M.J., K.M. Moore, M.L. Murray, and J.D. Kingston

1989 Detection of bone preservation in archaeological and fossil samples. Journal of Applied Geochemistry 4:281-292.

Scrimshaw, N.S., and J.P. SanGiovanni

1997 Synergism of nutrition, infection, and immunity: An overview. American Journal of Clinical Nutrition 66:464S477S.

Silverblatt, I.

1978 Andean women in the Inca Empire. Feminist Studies 4:36-61.

Slovak, N.M.

2007 Examining Imperial Influence on Peru's Central Coast: Isotopic and Cultural Analyses of Middle Horizon Burials at Ancon. Ph.D. Dissertation, Stanford University, Unpublished Ph.D. Dissertation.

Tieszen, L.L.

1991 Natural variations in the carbon isotope values of plantsimplications for archaeology, ecology and paleoecology. Journal of Archaeological Science 18:227-248.

Tieszen, L.L., T.W. Boutton, K.G. Tesdahl, and N.A. Slade

1983 Fractionation and turnover of stable cabon isotopes in animal tissues: Implications for $\delta 13 \mathrm{C}$ analysis of diet. Oecologia (Berlin) 57:32-37.

Tieszen, L.L., and M. Chapman

1993 Carbon and nitrogen isotopic status of the major marine and terrestrial resources in the Atacama Desert of Northern Chile. In First World Congress on Mummy Studies, edited by A. Aufderheide, pp. 409-426. World Congress on Mummy Studies, Santa Cruz, Tenerife.

Tomczak, P.D.

2003 Prehistoric diet and socioeconomic relationships within the Osmore Valley of Southern Peru. Journal of Anthropological Archaeology 22:262-278.

Turner, B.L.

2008 The Servants of Machu Picchu: Life Histories and Population Dynamics in Late Horizon Peru. Ph.D. Dissertation, Emory University, Unpublished Ph.D. Dissertation.
Turner, B.L., J.L. Edwards, E.A. Quinn, J.D. Kingston, and D.P. Van Gerven

2007 Age-related variation in isotopic indicators of diet at medieval Kulubnarti, Sudanese Nubia. International Journal of Osteoarchaeology, in press.

Turner, B.L., G.D. Kamenov, J.D. Kingston, and G.J. Armelagos

2009 Insights into Immigration and social class at Machu Picchu, Peru based on oxygen, strontium, and lead isotopic analysis. Journal of Archaeological Science 36:317-332.

Turner, B. L., J. D. Kingston, and G. J. Armelagos

2009 Diet versus locale: Isotopic support for causal roles in pathological conditions at Machu Picchu, Peru. American Journal of Physical Anthropology 132:401-402.

Ubelaker, D.H., M.A. Katzenberg, and L.G. Doyon 1995 Status and diet in precontact Highland Ecuador. American Journal of Physical Anthropology 97:403-411.

Verano, J.W.

2003 Human skeletal remains from Machu Picchu: A reexamination of the Yale Peabody Museum's collections. In The 1912 Yale Peruvian Scientific Expedition Collections from Machu Picchu: Human and Animal Remains, vol. 85, edited by R.L. Burger and L.C. Salazar, pp. 65-117 and Appendix A. Yale University Publications in Anthropology, New Haven.

Villar Córdova, $\mathrm{S}$

1966 La Institución del Yanacona in el Incanato. Vol. 1. Nueva Corónica. Universidad Nacional Mayor de San Marcos, Lima.

White, C.D., A.J. Nelson, F.J. Longstaffe, G. Grupe, and A. Jung

2009 Landscape bioarchaeology at Pacatnamu, Peru: Inferring mobility from $\delta^{13} \mathrm{C}$ and $\delta^{15} \mathrm{~N}$ values of hair. Journal of Archaeological Science 36:1527-1537.

White, C.D., and H.P. Schwarcz

1994 Temporal trends in stable isotopes for Nubian mummy tissues. American Journal of Physical Anthropology 93:165187.

Yacobaccio, H.D., M.R. Morales, and C.T. Samec

2009 Towards an isotopic ecology of herbivory in the Puna ecosystem: New results and patterns on Lama glama. International Journal of Osteoarchaeology 19:144-155. 